\title{
Development of a Catalytic Aromatic Decarboxylation Reaction
}

Joshua S. Dickstein, Carol A. Mulrooney, Erin M. O’Brien, Barbara J. Morgan, and Marisa C. Kozlowski*

Department of Chemistry, Roy and Diana Vagelos Laboratories, University of
Pennsylvania, Philadelphia, Pennsylvania 19104

Supporting Information

General Considerations $\quad$ S2

Synthesis of Decarboxylation Substrates $\quad$ S2-S7

Typical Decarboxylation Procedures S7-S8

GC Reaction Monitoring $\quad$ S8-S9

NMR Reaction Monitoring S9

Analytical Data for Decarboxylation Products S9-S13

Spectral Copies $\quad$ S14-S29 


\section{General Considerations}

Unless otherwise stated all solvents and reagents were ACS reagent grade and were used without further purification. DMSO and DMF were distilled from $\mathrm{BaO}$. Palladium (II) trifluoroacetate was purchased from either Acros or Strem. Analytical thin layer chromatography (TLC) was performed on EM Reagents $1.00 \mathrm{~mm}$ silica-gel plates. Due to the volatility of the products, rotary evaporation was avoided. Instead, the solvent was slowly evaporated on the bench-top. In addition, chromatography was performed with the most volatile solvent system possible and the fractions were also concentrated by slow evaporation on the bench-top.

${ }^{1} \mathrm{H}$ NMR and ${ }^{13} \mathrm{C}$ NMR spectra were recorded on a Bruker AM-500 (500 MHz) spectrometer. Chemical shifts are reported in parts per million (ppm) from tetramethylsilane $(0 \mathrm{ppm})$ or from the solvent resonance $\left(\mathrm{CDCl}_{3} 7.26 \mathrm{ppm}, \mathrm{DMSO}-\mathrm{d}_{6}\right.$ $2.54 \mathrm{ppm}$, Acetone- $\left.\mathrm{d}_{6} 2.09 \mathrm{ppm}\right)$. Data are reported as follows: chemical shift, multiplicity $(\mathrm{s}=$ singlet, $\mathrm{d}=$ doublet, $\mathrm{t}=$ triplet, $\mathrm{q}=$ quartet, $\mathrm{dd}=$ doublet of doublets, $\mathrm{br}=$ broad, $\mathrm{m}=$ multiplet), coupling constants, and number of protons. Mass spectra were obtained on a high resonance $\mathrm{VG}$ autospec with an ionization mode of either CI or ES. IR spectra were taken on an ASI ReactIR 1000 FT-IR spectrometer. GC analysis for reactions was conducted with an Agilent 6850 gas chromatograph with an HP-1 column (Agilent): length $=30 \mathrm{~m}, \mathrm{ID}=0.32 \mathrm{~mm}$, film $=0.25 \mathrm{~mm}$, flow $=2 \mathrm{~mL} / \mathrm{min}, 80{ }^{\circ} \mathrm{C}$ to 130 ${ }^{\circ} \mathrm{C}$. Carrier gas: $\mathrm{N}_{2}$; Detector: FID; Injector: $250{ }^{\circ} \mathrm{C}$; Pressure $21.25 \mathrm{psi}$ ). Melting points were obtained on Thomas Scientific Unimelt apparatus and are uncorrected. Yields refer to isolated material judged to be $\geq 95 \%$ pure by ${ }^{1} \mathrm{H}$ NMR spectroscopy following silica gel chromatography with Silia-P flash silica gel (50-63 $\mu \mathrm{m}$ mesh particle size).

\section{Synthesis of Decarboxylation Substrates}

1,3,7-trimethoxynaphthalene-2-carboxylic acid (2b). To a solution of methyl 1,3dihydroxy-7-methoxynaphthalene-2-carboxylate $(200 \mathrm{mg}, 0.85 \mathrm{mmol})$ in $3.9 \mathrm{~mL}$ of THF: $\mathrm{H}_{2} \mathrm{O}(1.0: 0.3), \mathrm{Bu}_{4} \mathrm{NBr}(28 \mathrm{mg}, 0.085 \mathrm{mmol})$ and $\mathrm{KOH}(478 \mathrm{mg}, 8.4 \mathrm{mmol})$ was added. To this solution dimethyl sulfate $(810 \mu \mathrm{L}, 8.4 \mathrm{mmol})$ was added and the reaction was stirred at room temperature for $4 \mathrm{~h}$. The reaction was quenched with $30 \% \mathrm{NH}_{4} \mathrm{OH}$ for $30 \mathrm{~min}$. The resultant mixture was extracted with $\mathrm{Et}_{2} \mathrm{O}$ and washed three times with $30 \% \mathrm{NH}_{4} \mathrm{OH}$ and one time with $\mathrm{H}_{2} \mathrm{O}$ and brine. The organic phase was dried over $\mathrm{Na}_{2} \mathrm{SO}_{4}$ and concentrated. The resulting residue was chromatographed in 5\% EtOAc/Hexanes to afford methyl 1,3,7-trimethoxynaphthalene-2-carboxylate (90 $\mathrm{mg}$ ) in $38 \%$ yield. mp 98-101 ${ }^{\circ} \mathrm{C} ;{ }^{1} \mathrm{H}$ NMR $\left(500 \mathrm{MHz}, \mathrm{CDCl}_{3}\right) \delta 7.62(\mathrm{~d}, J=9.0 \mathrm{~Hz}, 1 \mathrm{H}), 7.33$ 
$(\mathrm{d}, J=2.6 \mathrm{~Hz}, 1 \mathrm{H}), 7.16(\mathrm{dd}, J=9.0,2.7 \mathrm{~Hz}, 1 \mathrm{H}), 6.91(\mathrm{~s}, 1 \mathrm{H}), 4.01(\mathrm{~s}, 3 \mathrm{H}), 3.98(\mathrm{~s}, 3 \mathrm{H})$, 3.90 (s, 3H), 3.89 (s, 3H); ${ }^{13} \mathrm{C}$ NMR (125 MHz, $\left.\mathrm{CDCl}_{3}\right) \delta$ 167.2, 156.7, 153.4, 152.6, 130.7, 128.6, 123.8, 120.4, 117.7, 102.2, 101.1, 62.7, 56.0, 55.4, 52.6; IR (film) 3003, 2949, 2907, 2841, 1733, 1606, 1583, $1505 \mathrm{~cm}^{-1}$; HRMS (CI) calcd for $\mathrm{C}_{15} \mathrm{H}_{16} \mathrm{O}_{5}\left(\mathrm{M}^{+}\right)$ 276.0998 , found 276.0996 .

To a solution of methyl 1,3,7-trimethoxynaphthalene-2-carboxylate (90 mg, $0.33 \mathrm{mmol}$ ) in ethylene glycol was added $\mathrm{KOH}(500 \mathrm{mg}, 8.9 \mathrm{mmol})$. The suspension was then heated to $130{ }^{\circ} \mathrm{C}$ for $24 \mathrm{~h}$ under $\mathrm{N}_{2}$. The brown mixture was then acidified with concentrated $\mathrm{HCl}$ at $0{ }^{\circ} \mathrm{C}$ and extracted with EtOAc three times. The organic extracts were then washed with brine and dried over $\mathrm{Na}_{2} \mathrm{SO}_{4}$, filtered and concentrated. The resultant solid was dissolved in $\mathrm{CH}_{2} \mathrm{Cl}_{2}$ and extracted twice with $1 \mathrm{M} \mathrm{NaOH}$. The aqueous phase was then acidified and extracted three times with EtOAc. The organic extracts were then washed with brine, dried over $\mathrm{Na}_{2} \mathrm{SO}_{4}$, filtered and concentrated to afford $\mathbf{2 b}(77 \mathrm{mg}$ ) in 90\% yield. White powder; mp 204-205 ${ }^{\circ} \mathrm{C} ;{ }^{1} \mathrm{H}$ NMR $\left(500 \mathrm{MHz}, \mathrm{CDCl}_{3}\right) \delta 7.66(\mathrm{~d}, J=8.9$ $\mathrm{Hz}, 1 \mathrm{H}), 7.37$ (d, $J=2.4 \mathrm{~Hz}, 1 \mathrm{H}), 7.21$ (dd, $J=8.9,2.5 \mathrm{~Hz}, 1 \mathrm{H}), 6.98$ (s, 1H), 4.08 (s, 3H), 3.98 (s, 3H), 3.94 (s, 3H); ${ }^{13} \mathrm{C}$ NMR (125 MHz, DMSO) $\delta 166.9,156.3,151.9$, $151.6,129.8,128.8,123.2,119.8,119.4,102.4,100.7,62.3,55.7,55.2$; IR (thin film) 3105, 2972, 2887 (br), 1076, 1610, 1239, $1108 \mathrm{~cm}^{-1}$; HRMS (ESI) calcd for $\mathrm{C}_{14} \mathrm{H}_{13} \mathrm{O}_{4}$ (MOH) 245.0814 , found 245.0820 .

1,3,6,8-tetramethoxynaphthalene-2-carboxylic acid (2c). To a solution of methyl 1,3diacetoxy-6,8-dimethoxynaphthalene-2-carboxylate $(200 \mathrm{mg}, 0.55 \mathrm{mmol})$ in $20 \mathrm{~mL}$ of $\mathrm{MeOH}: \mathrm{CH}_{2} \mathrm{Cl}_{2}(1: 1)$, potassium carbonate $(1.0 \mathrm{~g})$ was added. The solution was then heated to $40{ }^{\circ} \mathrm{C}$ for $30 \mathrm{~min}$. The reaction mixture was then extracted into $\mathrm{CH}_{2} \mathrm{Cl}_{2}$ twice and then washed with $1 \mathrm{M} \mathrm{HCl}$ twice. The organic phase was then dried over $\mathrm{Na}_{2} \mathrm{SO}_{4}$, filtered, and concentrated to afford methyl 1-acetoxy-3-hydroxy-6,8dimethoxynaphthalene-2-carboxylate $(174 \mathrm{mg})$ in $98 \%$ yield. ${ }^{1} \mathrm{H}$ NMR $(500 \mathrm{MHz}$, $\left.\mathrm{CDCl}_{3}\right) \delta 10.82(\mathrm{~s}, 1 \mathrm{H}), 7.04(\mathrm{~s}, 1 \mathrm{H}), 6.50(\mathrm{~d}, J=2.2 \mathrm{~Hz}, 1 \mathrm{H}), 6.27(\mathrm{~d}, J=2.2 \mathrm{~Hz}, 1 \mathrm{H})$, $3.95(\mathrm{~s}, 3 \mathrm{H}), 3.86(\mathrm{~s}, 3 \mathrm{H}), 3.85(\mathrm{~s}, 3 \mathrm{H}), 2.35(\mathrm{~s}, 3 \mathrm{H})$.

To a solution of methyl 1-acetoxy-3-hydroxy-6,8-dimethoxynaphthalene-2-carboxylate (174 mg, $0.54 \mathrm{mmol})$ in DMF (5 mL), 60\% NaH (430 mg, $11 \mathrm{mmol})$ and $\mathrm{MeI}(840 \mu \mathrm{L}$, $14 \mathrm{mmol}$ ) was added under $\mathrm{N}_{2}$. The reaction was stirred at room temperature for $2 \mathrm{~h}$ and then quenched with $30 \% \mathrm{NH}_{4} \mathrm{OH}$. The reaction mixture was then extracted into $\mathrm{Et}_{2} \mathrm{O}$ and washed twice with $30 \% \mathrm{NH}_{4} \mathrm{OH}$ and once with brine. The organic extracts were then 
dried over $\mathrm{Na}_{2} \mathrm{SO}_{4}$ and concentrated. The resulting residue was chromatographed in $20 \%$ EtOAc/Hexanes to afford methyl 1-hydroxy-3,6,8-trimethoxynaphthalene-2-carboxylate (78 mg) in $49 \%$ yield.

To a solution of methyl 1-hydroxy-3,6,8-trimethoxynaphthalene-2-carboxylate (78 mg, $0.27 \mathrm{mmol})$ in $2.6 \mathrm{~mL}$ of THF: $\mathrm{H}_{2} \mathrm{O}(1.0: 0.3), \mathrm{Bu}_{4} \mathrm{NBr}(8.6 \mathrm{mg}, 0.027 \mathrm{mmol})$ and $\mathrm{KOH}$ (150 mg, $2.7 \mathrm{mmol}$ ) was added. The solution was cooled to $0{ }^{\circ} \mathrm{C}$ and dimethyl sulfate $(250 \mu \mathrm{L}, 2.7 \mathrm{mmol})$ was added and the reaction was stirred at $0{ }^{\circ} \mathrm{C}$ for $4 \mathrm{~h}$. The reaction was quenched with $30 \% \mathrm{NH}_{4} \mathrm{OH}$ for $30 \mathrm{~min}$. The resultant mixture was extracted with $\mathrm{Et}_{2} \mathrm{O}$ and washed three times with $30 \% \mathrm{NH}_{4} \mathrm{OH}$ and one time with $\mathrm{H}_{2} \mathrm{O}$ and brine. The organic phase was dried over $\mathrm{Na}_{2} \mathrm{SO}_{4}$, filtered, and concentrated to afford methyl 1,3,6,8tetramethoxynaphthalene-2-carboxylate $(66 \mathrm{mg})$ in $81 \%$ yield. $\mathrm{mp} 137-137.5{ }^{\circ} \mathrm{C} ;{ }^{1} \mathrm{H}$ NMR $\left(500 \mathrm{MHz}, \mathrm{CDCl}_{3}\right) \delta 6.81(\mathrm{~s}, 1 \mathrm{H}), 6.64(\mathrm{~d}, J=2.2 \mathrm{~Hz}, 1 \mathrm{H}), 6.39(\mathrm{~d}, J=2.2 \mathrm{~Hz}$, $1 \mathrm{H}), 3.94(\mathrm{~s}, 3 \mathrm{H}), 3.93$ (s, 3H), 3.88 (s, 3H), 3.877 (s, 3H), 3.86 (s, 3H); ${ }^{13} \mathrm{C}$ NMR (125 $\left.\mathrm{MHz}, \mathrm{CDCl}_{3}\right) \delta 167.2,159.5,157.7,155.4,154.9,139.3,117.1,110.6,102.1,98.6,97.4$, 63.9, 56.0, 55.8, 55.4, 52.5; IR (film) 2995, 2937, 2837, 1729, 1621, 1583, $1447 \mathrm{~cm}^{-1}$; HRMS (CI) calcd for $\mathrm{C}_{16} \mathrm{H}_{18} \mathrm{O}_{6}\left(\mathrm{M}^{+}\right) 306.1103$, found 306.1095.

To a solution of methyl 1,3,6,8-tetramethoxynaphthalene-2-carboxylate (58 mg, 0.19 mmol) in $10 \mathrm{~mL}$ of dioxane, $10 \mathrm{~mL}$ of conc. $\mathrm{LiOH} / \mathrm{H}_{2} \mathrm{O}$ was added. The resulting solution was heated to reflux for $24 \mathrm{~h}$. The reaction mixture was then acidified with concentrated $\mathrm{HCl}$ and extracted with $\mathrm{CH}_{2} \mathrm{Cl}_{2}$ three times. The organic extracts were then washed with brine and dried over $\mathrm{Na}_{2} \mathrm{SO}_{4}$, filtered and concentrated. The resultant solid was dissolved in $\mathrm{CH}_{2} \mathrm{Cl}_{2}$ and extracted twice with $1 \mathrm{M} \mathrm{NaOH}$. This solution was then acidified and extracted three times with EtOAc. The organic extracts were then washed with brine, dried over $\mathrm{Na}_{2} \mathrm{SO}_{4}$, filtered and concentrated to afford $2 \mathrm{c}(41 \mathrm{mg})$ in $75 \%$ yield. White crystalline solid; mp 154-158 ${ }^{\circ} \mathrm{C} ;{ }^{1} \mathrm{H}$ NMR $\left(500 \mathrm{MHz}, \mathrm{CDCl}_{3}\right) \delta 6.67$ (s, $1 \mathrm{H}), 6.55(\mathrm{~d}, J=2.0 \mathrm{~Hz}, 1 \mathrm{H}), 6.35(\mathrm{~d}, J=2.1 \mathrm{~Hz}, 1 \mathrm{H}), 3.93$ (s, 3H), 3.90 (s, 3H), 3.89 (s, 3H), 3.88 (s, 3H); ${ }^{13} \mathrm{C}$ NMR (125 MHz, $\mathrm{CDCl}_{3}$ ) $8169.8,159.7,157.6,155.1,154.7,139.3$, 116.2, 110.3, 102.3, 98.5, 97.3, 64.1, 56.0, 55.9, 55.4; IR (film) 3069, 3003, 2934, 2856, $2660,2559,1698,1621,1583,1455,1432 \mathrm{~cm}^{-1}$; HRMS (ES) calcd for $\mathrm{C}_{15} \mathrm{H}_{16} \mathrm{O}_{6}\left(\mathrm{MH}^{+}\right)$ 293.1025 , found 293.1027 .

1,3,6,7-tetramethoxynaphthalene-2-carboxylic acid (2d). To a solution of methyl 1,3dihydroxy-6,7-dimethoxynaphthalene-2-carboxylate $(200 \mathrm{mg}, 0.72 \mathrm{mmol})$ in $6.5 \mathrm{~mL}$ of THF: $\mathrm{H}_{2} \mathrm{O}(1.0: 0.3), \mathrm{Bu}_{4} \mathrm{NBr}(23 \mathrm{mg}, 0.072 \mathrm{mmol})$ and $\mathrm{KOH}(400 \mathrm{mg}, 7.2 \mathrm{mmol})$ was 
added. To this solution dimethyl sulfate $(680 \mu \mathrm{L}, 7.2 \mathrm{mmol})$ was added and the reaction was stirred at room temperature for $4 \mathrm{~h}$. The reaction was quenched with $30 \% \mathrm{NH}_{4} \mathrm{OH}$ for $30 \mathrm{~min}$. The resultant mixture was extracted with $\mathrm{Et}_{2} \mathrm{O}$ and washed three times with $30 \% \mathrm{NH}_{4} \mathrm{OH}$ and once with $\mathrm{H}_{2} \mathrm{O}$ and brine. The organic phase was dried over $\mathrm{Na}_{2} \mathrm{SO}_{4}$ and concentrated. The resulting residue was chromatographed in 30\% EtOAc/Hexanes to afford methyl 1,3,6,7-tetramethoxynaphthalene-2-carboxylate $(57 \mathrm{mg})$ in $25 \%$ yield. $\mathrm{mp}$ 114-117 ${ }^{\circ} \mathrm{C} ;{ }^{1} \mathrm{H}$ NMR (500 MHz, $\mathrm{CDCl}_{3}$ ) $\delta 7.29$ (s, 1H), 7.03 (s, 1H), 6.84 (s, 1H), 3.98 $(\mathrm{s}, 3 \mathrm{H}), 3.97$ (s, 6H), $3.96(\mathrm{~s}, 3 \mathrm{H}), 3.88(\mathrm{~s}, 3 \mathrm{H}) ;{ }^{13} \mathrm{C} \mathrm{NMR}\left(125 \mathrm{MHz}, \mathrm{CDCl}_{3}\right) \delta 167.3$, 153.6, 153.4, 151.1, 148.3, 131.6, 117.8, 115.2, 106.0, 101.5, 101.4, 62.8, 56.0 (2), 55.9, 52.6; IR (film) 2999, 2949, 2872, 2845, 1729, 1625, 1602, $1583 \mathrm{~cm}^{-1}$.

To a solution of methyl 1,3,6,7-tetramethoxynaphthalene-2-carboxylate (58 $\mathrm{mg}, 0.19$ $\mathrm{mmol})$ in $\mathrm{MeOH}(3 \mathrm{~mL})$, concentrated $\mathrm{NaOH}(3 \mathrm{~mL})$ was added. The solution was then heated to $40{ }^{\circ} \mathrm{C}$ for 1 day. The reaction mixture was then acidified with concentrated $\mathrm{HCl}$ and then extracted with $\mathrm{CH}_{2} \mathrm{Cl}_{2}$ three times. The organic extracts were then washed with brine and dried over $\mathrm{Na}_{2} \mathrm{SO}_{4}$, filtered, and concentrated to afford $2 \mathbf{d}(55 \mathrm{mg})$ in quantitative yield. White crystalline solid; mp 168-171 ${ }^{\circ} \mathrm{C} ;{ }^{1} \mathrm{H} \mathrm{NMR}\left(500 \mathrm{MHz}, \mathrm{CDCl}_{3}\right) \delta$ 7.34 (s, 1H), 7.04 (s, 1H), 6.90 (s, 1H), 4.07 (s, 3H), 4.003 (s, 3H), 3.999 (s, 3H), 3.96 (s, $3 \mathrm{H}) ;{ }^{13} \mathrm{C}$ NMR $\left(125 \mathrm{MHz}, \mathrm{CDCl}_{3}\right) \delta 169.7,155.2,153.6,151.6,148.6,132.1,118.3$, 113.6, 106.0, 101.9, 101.8, 63.2, 56.3, 56.1, 56.0; IR (film) 3532, 3003, 2937, 2853, 2625, 2023, 1702, 1629, 1610, 1583, 1509, $1482 \mathrm{~cm}^{-1}$; HRMS (ES) calcd for $\mathrm{C}_{15} \mathrm{H}_{16} \mathrm{O}_{6}$ $\left(\mathrm{MNa}^{+}\right) 315.0845$, found 315.0838.

1,3,6,7-tetramethoxy-4-methylnaphthalene-2-carboxylic acid (2e). To a solution of methyl 1,3-dihydroxy-6,7-dimethoxynaphthalene-2-carboxylate (200 $\mathrm{mg}, 0.72 \mathrm{mmol})$ in $6.5 \mathrm{~mL}$ of $\mathrm{THF}: \mathrm{H}_{2} \mathrm{O}(1.0: 0.3), \mathrm{Bu}_{4} \mathrm{NBr}(23 \mathrm{mg}, 0.072 \mathrm{mmol})$ and $\mathrm{KOH}(400 \mathrm{mg}, 7.2$ mmol) was added. To this solution dimethyl sulfate $(680 \mu \mathrm{L}, 7.2 \mathrm{mmol})$ was added and the reaction was stirred at room temperature for $4 \mathrm{~h}$. The reaction was quenched with $30 \% \mathrm{NH}_{4} \mathrm{OH}$ for 30 min. The resultant mixture was extracted with $\mathrm{Et}_{2} \mathrm{O}$ and washed three times with $30 \% \mathrm{NH}_{4} \mathrm{OH}$ and one time with $\mathrm{H}_{2} \mathrm{O}$ and brine. The organic phase was dried over $\mathrm{Na}_{2} \mathrm{SO}_{4}$ and concentrated. The resulting residue was chromatographed in $30 \%$ EtOAc/Hexanes to afford methyl 1,3,6,7-tetramethoxy-4-methylnaphthalene-2carboxylate $(58 \mathrm{mg})$ in $26 \%$ yield. mp $124-126{ }^{\circ} \mathrm{C} ;{ }^{1} \mathrm{H}$ NMR $\left(500 \mathrm{MHz}, \mathrm{CDCl}_{3}\right) \delta 7.37$ (s, 1H), 7.15 (s, 1H), 4.01 (s, 3H), 4.00 (s, 3H), 3.98 (s, 3H), 3.97 (s, 3H), $3.81(\mathrm{~s}, 3 \mathrm{H})$, 2.49 (s, 3H); ${ }^{13} \mathrm{C}$ NMR (125 MHz, $\mathrm{CDCl}_{3}$ ) $\delta$ 167.5, 151.4, 150.9, 150.8, 149.0, 130.8, 120.2 , 120.1, 118.6, 103.4, 101.7, 62.8, 62.6, 56.0, 55.9, 52.5, 11.5; IR (film) 3003, 
2949, 2907, 2837, 1729, 1620, $1610 \mathrm{~cm}^{-1}$; HRMS (ES) calcd for $\mathrm{C}_{17} \mathrm{H}_{20} \mathrm{O}_{6}\left(\mathrm{MNa}^{+}\right)$ 343.1158 , found 343.1167 .

To a solution of methyl 1,3,6,7-tetramethoxy-4-methylnaphthalene-2-carboxylate $(55 \mathrm{mg}$, $0.17 \mathrm{mmol}$ ) in $10 \mathrm{~mL}$ of dioxane, $10 \mathrm{~mL}$ of conc. $\mathrm{LiOH} / \mathrm{H}_{2} \mathrm{O}$ was added. The resulting solution was heated to reflux for $24 \mathrm{~h}$. The reaction mixture was then acidified with concentrated $\mathrm{HCl}$ and extracted with $\mathrm{CH}_{2} \mathrm{Cl}_{2}$ three times. The organic extracts were then washed with brine and dried over $\mathrm{Na}_{2} \mathrm{SO}_{4}$, filtered and concentrated. The resultant solid was dissolved in $\mathrm{CH}_{2} \mathrm{Cl}_{2}$ and extracted twice with $1 \mathrm{M} \mathrm{NaOH}$. This solution was then acidified and extracted three times with EtOAc. The organic extracts were then washed with brine, dried over $\mathrm{Na}_{2} \mathrm{SO}_{4}$, filtered and concentrated to afford $2 \mathrm{e}(51 \mathrm{mg})$ in $97 \%$ yield. White crystalline solid; mp 174-179 ${ }^{\circ} \mathrm{C} ;{ }^{1} \mathrm{H}$ NMR $\left(500 \mathrm{MHz}, \mathrm{CDCl}_{3}\right) \delta 7.38$ (s, $1 \mathrm{H}), 7.13(\mathrm{~s}, 1 \mathrm{H}), 4.05(\mathrm{~s}, 3 \mathrm{H}), 4.03(\mathrm{~s}, 3 \mathrm{H}), 4.02(\mathrm{~s}, 3 \mathrm{H}), 3.89(\mathrm{~s}, 3 \mathrm{H}), 2.50(\mathrm{~s}, 3 \mathrm{H}) ;{ }^{13} \mathrm{C}$ NMR (125 MHz, $\left.\mathrm{CDCl}_{3}\right) \delta$ 170.4, 152.6, 151.2, 151.0, 149.2, 131.3, 120.6, 120.5, 117.1, 103.4, 101.9, 63.3, 62.9, 56.1, 56.0, 11.6; IR (film) 3516, 2999, 2941, 2872, 2837, 2636, 2602, 1729, 1702, 1625, 1602, 1583, 1509, 1475, $1428 \mathrm{~cm}^{-1}$; HRMS (ES) calcd for $\mathrm{C}_{16} \mathrm{H}_{18} \mathrm{O}_{6}\left(\mathrm{MNa}^{+}\right)$329.1001, found 329.1016.

\section{5,5'-bis-benzyloxy-2,4,6,2',4',6'-hexamethoxy-7,7'-dipropyl-[1,1']-binaphthalenyl-}

3,3'-dicarboxylic acid (4). To a solution of $68 \%$ ee 5,5'-2,4,6,2',4',6'-hexamethoxy7,7'-dipropyl-[1,1']-binaphthalenyl-3,3'-dicarboxylic acid dimethyl ester (37 mg, 0.055 mmol) and benzyl bromide ( $46 \mu \mathrm{L}, 0.38 \mathrm{mmol})$ in DMF $(1.0 \mathrm{~mL})$ under an $\mathrm{Ar}$ atmosphere was added $60 \% \mathrm{NaH}(13 \mathrm{mg}, 0.31 \mathrm{mmol})$. The dark green mixture was stirred for $15 \mathrm{~h}$, quenched with $\mathrm{H}_{2} \mathrm{O}$, and washed with EtOAc. The organic phase was washed with $\mathrm{H}_{2} \mathrm{O}$ and brine, and dried $\left(\mathrm{Na}_{2} \mathrm{SO}_{4}\right)$ and the solvent evaporated to yield an orange oil. Purification was accomplished by chromatography (15\% EtOAc/Hexanes) to yield 5,5'-bis-benzyloxy-2,4,6,2',4',6'-hexamethoxy-7,7'-dipropyl-[1,1']-binaphthalenyl$3,3^{\prime}$-dicarboxylic acid dimethyl ester $(36 \mathrm{mg})$ in $78 \%$ yield as a yellow resin; $[\alpha]^{20}{ }_{\mathrm{D}}-24.7$ (c 1.0, $\mathrm{CHCl}_{3}, 68 \%$ ee); ${ }^{1} \mathrm{H}$ NMR $\left(500 \mathrm{MHz}, \mathrm{CDCl}_{3}\right) \delta 7.63$ (d, $\left.J=7.0 \mathrm{~Hz}, 4 \mathrm{H}\right), 7.44$ (t, $J$ $=7.3 \mathrm{~Hz}, 4 \mathrm{H}), 7.38(\mathrm{t}, J=7.3 \mathrm{~Hz}, 2 \mathrm{H}), 6.76(\mathrm{~s}, 2 \mathrm{H}), 5.09(\mathrm{~m}, 4 \mathrm{H}), 4.00(\mathrm{~s}, 6 \mathrm{H}), 3.98(\mathrm{~s}$, $6 \mathrm{H}), 3.95(\mathrm{~s}, 6 \mathrm{H}), 3.39$ (s, 6H), 2.49-2.54 (m, 4H), 1.39-1.43 (m, 4H), $0.75(\mathrm{t}, J=7.4 \mathrm{~Hz}$, $6 \mathrm{H}) ;{ }^{13} \mathrm{C}$ NMR $\left(125 \mathrm{MHz}, \mathrm{CDCl}_{3}\right) \delta 167.8,154.4,152.6,146.8,138.9,138.4,133.8$, 129.2, 128.8, 128.3, 127.4, 123.1, 120.7, 120.3, 114.2, 77.1, 64.6, 62.3, 60.9, 53.2, 33.2, 23.9, 14.2; IR (thin film) 2939, 1735, 1330, $1094 \mathrm{~cm}^{-1}$; HRMS (ESI) calcd for $\mathrm{C}_{50} \mathrm{H}_{54} \mathrm{O}_{12} \mathrm{Na}\left(\mathrm{MNa}^{+}\right)$869.3513, found 869.3541. 
To a suspension of 5,5'-bis-benzyloxy-2,4,6,2',4',6'-hexamethoxy-7,7'-dipropyl-[1,1']binaphthalenyl-3,3'-dicarboxylic acid dimethyl ester (163 $\mathrm{mg}, 0.19 \mathrm{mmol})$ in dioxane (8 $\mathrm{mL})$ and $\mathrm{H}_{2} \mathrm{O}(9 \mathrm{~mL})$ was added $\mathrm{LiOH} \cdot \mathrm{H}_{2} \mathrm{O}(402 \mathrm{mg}, 9.6 \mathrm{mmol})$ and the mixture was heated to reflux for $24 \mathrm{~h}$. The brown mixture was cooled to room temperature and diluted with $\mathrm{H}_{2} \mathrm{O}$. The aqueous phase was washed with EtOAc and this organic phase was washed with $\mathrm{H}_{2} \mathrm{O}$ and brine, dried $\left(\mathrm{Na}_{2} \mathrm{SO}_{4}\right)$, and the solvent evaporated to recover $73 \mathrm{mg}(0.086 \mathrm{mmol}, 45 \%)$ of the starting material. The aqueous phase was acidified with $1 \mathrm{~N} \mathrm{HCl}$, extracted with EtOAc, and the organic phase was washed with $\mathrm{H}_{2} \mathrm{O}$ and brine, dried $\left(\mathrm{Na}_{2} \mathrm{SO}_{4}\right)$, and the solvent evaporated to yield $4(81 \mathrm{mg})$ in $54 \%$ yield as an orange resin that was used without further purification; ${ }^{1} \mathrm{H} \mathrm{NMR}\left(500 \mathrm{MHz}, \mathrm{CDCl}_{3}\right) \delta 9.00$ (br s, 2H), $7.64(\mathrm{~d}, J=7.0 \mathrm{~Hz}, 4 \mathrm{H}), 7.43(\mathrm{t}, J=7.3 \mathrm{~Hz}, 4 \mathrm{H}), 7.36(\mathrm{t}, J=7.3 \mathrm{~Hz}, 2 \mathrm{H}), 6.80$ (s, 2H), $5.11(\mathrm{dd}, J=9.8,14.9 \mathrm{~Hz}, 4 \mathrm{H}), 3.99$ (s, 6H), 3.98 (s, 6H), 3.44 (s, 6H), 2.50-2.54 (m, 4H), 1.40-1.44 (m, 4H), $0.76(\mathrm{t}, J=7.3 \mathrm{~Hz}, 6 \mathrm{H})$; HRMS (ESI) calcd for $\mathrm{C}_{48} \mathrm{H}_{50} \mathrm{O}_{12} \mathrm{Na}$ $\left(\mathrm{MNa}^{+}\right)$841.3200, found 841.3240.

\section{Typical Decarboxylation Procedures}

Typical procedure for substituted aromatics 3a, 3c, and 3d (Table 1: entries 1, 3, and 4). To a solution of $\mathbf{2 d}(20 \mathrm{mg}, 0.068 \mathrm{mmol})$ in 5\% DMSO/DMF (1 mL), palladium (II) trifluoroacetate $(4.6 \mathrm{mg}, 0.014 \mathrm{mmol})$ was added. To this solution was added trifluoroacetic acid $(51 \mu \mathrm{L}, 0.68 \mathrm{mmol})$. The reaction mixture was heated at $70^{\circ} \mathrm{C}$ for 24 h. After cooling, the mixture was diluted with $\mathrm{Et}_{2} \mathrm{O}$, and washed sequentially with $1 \mathrm{M}$ $\mathrm{HCl}$, saturated $\mathrm{NH}_{4} \mathrm{Cl}, \mathrm{H}_{2} \mathrm{O}$, and brine. The organic extracts were dried over $\mathrm{Na}_{2} \mathrm{SO}_{4}$ and concentrated at ambient temperature and pressure by slow evaporation on the bench-top. The resulting residue was chromatographed in $10 \% \mathrm{Et}_{2} \mathrm{O} /$ pentane to afford $\mathbf{3 d}(13.0 \mathrm{mg})$ in $74 \%$ yield.

Typical procedure for substituted aromatics $3 \mathrm{~b}$ and $3 \mathrm{e}$ (Table 1: entries 2 and 5). To a solution of $\mathbf{2 b}(10 \mathrm{mg}, 0.038 \mathrm{mmol})$ in $5 \% \mathrm{DMSO} / \mathrm{DMF}(0.5 \mathrm{~mL})$, palladium (II) trifluoroacetate $(2.5 \mathrm{mg}, 0.0076 \mathrm{mmol})$ was added. To this solution was added trifluoroacetic acid $(28 \mu \mathrm{L}, 0.38 \mathrm{mmol})$. The reaction mixture was heated at $80^{\circ} \mathrm{C}$ for 24 h. After cooling, the mixture was diluted with $\mathrm{Et}_{2} \mathrm{O}$, and washed sequentially with $1 \mathrm{M}$ $\mathrm{HCl}$, saturated $\mathrm{NH}_{4} \mathrm{Cl}, \mathrm{H}_{2} \mathrm{O}$, and brine. The organic extracts were then dried over $\mathrm{Na}_{2} \mathrm{SO}_{4}$ and concentrated at ambient temperature and pressure by slow evaporation on the benchtop. The resulting residue was chromatographed in $10 \% \mathrm{Et}_{2} \mathrm{O} /$ pentane to afford $\mathbf{3 b}$ (6.0 $\mathrm{mg}$ ) in $71 \%$ yield. 
Typical procedure for substituted benzenes $3 f$ and $3 g$ (Table 2: entries 6 and 7). To a solution of 2,4,5-trimethoxybenzoic acid (300 mg, $1.4 \mathrm{mmol}$ ) in $\mathrm{MeOH}$ (15 mL) was added potassium tert-butoxide $(160 \mathrm{mg}, 1.4 \mathrm{mmol})$. The suspension was then stirred at room temperature for $4 \mathrm{~h}$ and then concentrated by rotary evaporation to afford $2 \mathbf{f}$ (344 $\mathrm{mg}$ ) in $97 \%$ yield and was used without further purification.

To a solution of $2 \mathbf{f}(150 \mathrm{mg}, 0.60 \mathrm{mmol})$ in DMSO (4.5 mL), palladium (II) trifluoroacetate $\left(240 \mathrm{mg}, 0.72 \mathrm{mmol}\right.$ ) was added. This solution was heated to $80{ }^{\circ} \mathrm{C}$ for $30 \mathrm{~min}$. Then trifluoroacetic acid $(450 \mu \mathrm{L}, 6.00 \mathrm{mmol})$ was added and the solution was heated at $70{ }^{\circ} \mathrm{C}$ overnight. After cooling, the mixture was diluted with $\mathrm{Et}_{2} \mathrm{O}$ and washed three times with saturated $\mathrm{NH}_{4} \mathrm{Cl}$, three times with $\mathrm{H}_{2} \mathrm{O}$, and once with brine. The organic extracts were dried over $\mathrm{Na}_{2} \mathrm{SO}_{4}$ and concentrated at ambient temperature and pressure by slow evaporation on the bench-top. The resultant residue was chromatographed in $20 \% \mathrm{Et}_{2} \mathrm{O} /$ Pentane to afford $\mathbf{3 f}(55 \mathrm{mg})$ in $55 \%$ yield.

Typical procedure for compounds $3 \mathrm{~h}$ and $3 \mathrm{i}$ (Table 2: entries 8 and 9). To a solution of $\mathbf{2 h}(15 \mathrm{mg}, 0.021 \mathrm{mmol},>99 \%$ ee $(\mathrm{S}))$ in 5\% DMSO-DMF (1 mL) was added palladium (II) trifluoroacetate $(17 \mathrm{mg}, 0.052 \mathrm{mmol})$ and $\mathrm{Ag}_{2} \mathrm{CO}_{3}(35 \mathrm{mg}, 0.13 \mathrm{mmol})$. The mixture was heated in a $75^{\circ} \mathrm{C}$ oil bath for $1 \mathrm{~h}$. The reaction was removed from the oil bath and quenched with $\mathrm{NaBH}_{4}(4.0 \mathrm{mg}, 0.11 \mathrm{mmol})$. The black mixture was diluted with EtOAc, and the organic phase washed with $1 \mathrm{~N} \mathrm{HCl}$ and brine, dried $\left(\mathrm{Na}_{2} \mathrm{SO}_{4}\right)$, and the solvent was evaporated. Purification was accomplished via chromatography $(50 \%$ EtOAc/Hexanes) to yield $\mathbf{3 h}(8.5 \mathrm{mg}, 64 \%)$ as an oil (>99\% ee).

Typical procedure for compounds $3 \mathrm{~b}$ and 5 (Scheme 2). To a solution of 4 (27 $\mathrm{mg}$, $0.033 \mathrm{mmol})$ in $5 \% \mathrm{DMSO} / \mathrm{DMF}(0.3 \mathrm{~mL})$ was added palladium (II) trifluoroacetate (23 $\mathrm{mg}, 0.074 \mathrm{mmol})$. The mixture was then heated to $90^{\circ} \mathrm{C}$ for $1 \mathrm{~h}$. After cooling, $1 \mathrm{~N} \mathrm{HCl}$ was added and the mixture was extracted with EtOAc. The organic phase was washed with $\mathrm{H}_{2} \mathrm{O}$ and brine, dried over $\mathrm{Na}_{2} \mathrm{SO}_{4}$ and concentrated to yield a brown oil. This material was then dissolved in THF $(1.0 \mathrm{~mL})$ and stirred under a $\mathrm{H}_{2}$ atmosphere for 5 min. After filtration through Celite ${ }^{\circledR}$, the material was chromatographed in $20 \%$ EtOAc/Hexanes to afford 5 (21 mg) in $87 \%$ yield.

\section{GC Reaction Monitoring}

Monitoring the conversion of 2a to 3a. To a solution of $2 \mathbf{a}(60 \mathrm{mg}, 0.33 \mathrm{mmol})$ in $5 \%$ DMSO/DMF (3 mL), palladium (II) trifluoroacetate (110 mg, $0.33 \mathrm{mmol})$ and biphenyl 
(51 mg, $0.33 \mathrm{mmol})$ was added. To this solution was added trifluoroacetic acid $(250 \mu \mathrm{L}$, $3.3 \mathrm{mmol}$ ). The reaction mixture was then heated at $70{ }^{\circ} \mathrm{C}$ for $24 \mathrm{~h}$. At regular intervals, aliquots $(\sim 100 \mu \mathrm{L})$ removed. To this aliquot was added $1 \mathrm{M} \mathrm{HCl}$ and EtOAc. The solution was then shaken and the organic phase was filtered through $\mathrm{SiO}_{2}(10 \%$ $\mathrm{MeOH} / \mathrm{CH}_{2} \mathrm{Cl}_{2}$ ). The reaction progress was monitored by gas chromatography (GC). Retention times; 2a: $9.93 \mathrm{~min}, 3 \mathbf{3 a}$ : $1.60 \mathrm{~min}$, Biphenyl (Internal Standard): $5.50 \mathrm{~min}$. Correction factor for $\mathbf{2} \mathbf{a} ; \mathrm{y}=1.8 \mathrm{x}+0.085$. Correction factor for $\mathbf{3 a} ; \mathrm{y}=1.74 \mathrm{x}+0.11$.

\section{NMR Reaction Monitoring}

Procedure for NMR experiment 1. To a solution of $\mathbf{2 a}(12 \mathrm{mg}, 0.066 \mathrm{mmol})$ in DMSO-d $_{6}(0.75 \mathrm{ml})$ was added palladium (II) trifluoroacetate $(26 \mathrm{mg}, 0.079 \mathrm{mmol})$ and methanesulfonic acid (43 $\mu \mathrm{L}, 0.66 \mathrm{mmol})$. A ${ }^{1} \mathrm{H}$ NMR spectrum was then taken. The mixture was then warmed to $65^{\circ} \mathrm{C}$ and a spectrum was taken every $20 \min$ for $7 \mathrm{~h}$. The mixture was then cooled after $13 \mathrm{~h}$ at $65^{\circ} \mathrm{C}$ and a final spectrum was taken.

Procedure for NMR experiment 2. To a solution of 2,6-dimethoxybenzoic acid 2a (12 $\mathrm{mg}, 0.066 \mathrm{mmol})$ in $\mathrm{DMSO}-\mathrm{d}_{6}(0.75 \mathrm{~mL})$ was added palladium (II) trifluoroacetate (26 $\mathrm{mg}, 0.079 \mathrm{mmol}$ ) was added. The mixture was then heated at $70{ }^{\circ} \mathrm{C}$ for $6 \mathrm{~h}$. The mixture was cooled and methanesulfonic acid $(43 \mu \mathrm{L}, 0.66 \mathrm{mmol})$ was added. A ${ }^{1} \mathrm{H}$ NMR spectrum was then taken. The mixture was then warmed to $65^{\circ} \mathrm{C}$ and a spectrum was taken every $20 \mathrm{~min}$ for $9 \mathrm{~h}$. The mixture was then cooled after $12 \mathrm{~h}$ at $65^{\circ} \mathrm{C}$ and a final spectrum was taken.

\section{Analytical Data for Decarboxylation Products}

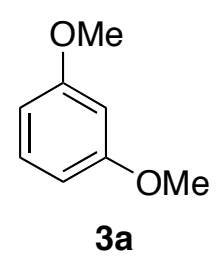

1,3-Dimethoxybenzene (3a): Pale yellow oil; ${ }^{1} \mathrm{H}$ NMR $\left(500 \mathrm{MHz}, \mathrm{CDCl}_{3}\right) \delta 7.19$ (t, $J=$ $8.2 \mathrm{~Hz}, 1 \mathrm{H}), 6.52$ (dd, $J=2.4,8.2 \mathrm{~Hz}, 2 \mathrm{H}), 6.48$ (t, $J=2.4 \mathrm{~Hz}, 1 \mathrm{H}), 3.80$ (s, 6H). Spectral data agreed with those reported previously: Saa, J. M.; Dopico, M.; Martonell, G.; Garcia-Raso, A. J. Org. Chem. 1994, 55, 991-995. 


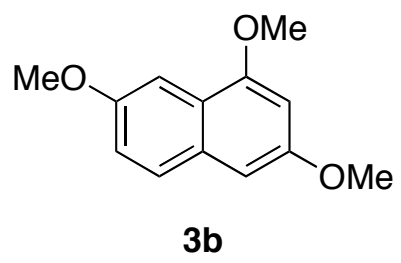

1,3,7-Trimethoxynaphthalene (3b): Brown amorphous solid; mp 69-71 ${ }^{\circ} \mathrm{C} ;{ }^{1} \mathrm{H}$ NMR $\left(500 \mathrm{MHz}, \mathrm{CDCl}_{3}\right) \delta 7.59$ (d, $\left.J=8.9 \mathrm{~Hz}, 1 \mathrm{H}\right), 7.47(\mathrm{~d}, J=2.6 \mathrm{~Hz}, 1 \mathrm{H}), 7.13$ (dd, $J=8.9$, $2.6 \mathrm{~Hz}, 1 \mathrm{H}), 6.70(\mathrm{~d}, J=2.1 \mathrm{~Hz}, 1 \mathrm{H}), 6.52(\mathrm{~d}, J=2.2 \mathrm{~Hz}, 1 \mathrm{H}), 3.98(\mathrm{~s}, 3 \mathrm{H}), 3.91(\mathrm{~s}, 3 \mathrm{H})$, 3.89 (s, 3H); ${ }^{13} \mathrm{C}$ NMR $\left(125 \mathrm{MHz}, \mathrm{CDCl}_{3}\right) \delta 156.6,156.0,155.7,130.2,128.1,122.3$, 119.5, 100.9, 98.2, 98.1, 55.7, 55.5, 55.4; IR (film) 2988, 2945, 2907, 1737, $1606 \mathrm{~cm}^{-1}$; HRMS (CI) calcd for $\mathrm{C}_{13} \mathrm{H}_{14} \mathrm{O}_{3}\left(\mathrm{M}^{+}\right)$218.0943, found 218.0939.

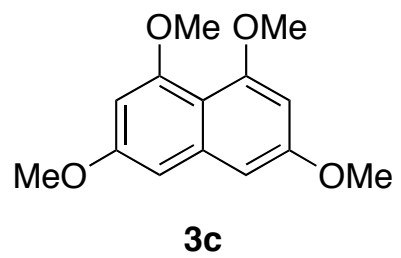

1,3,6,8-tetramethoxynaphthalene (3c): Black crystalline solid; ${ }^{1} \mathrm{H}$ NMR $(500 \mathrm{MHz}$, $\left.\mathrm{CDCl}_{3}\right) \delta 6.63(\mathrm{~d}, J=2.2 \mathrm{~Hz}, 2 \mathrm{H}), 6.37$ (d, $\left.J=2.2 \mathrm{~Hz}, 2 \mathrm{H}\right), 3.92(\mathrm{~s}, 6 \mathrm{H}), 3.88(\mathrm{~s}, 6 \mathrm{H})$. Spectral data agreed with those reported previously: McCulloch M. W. B.; Malcolm, W. B.; Barrow, R. A. Tetrahedron Lett. 2005, 46, 7619-7621.

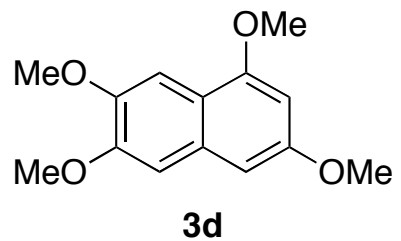

1,3,6,7-tetramethoxynaphthalene (3d): Dark brown amorphous solid; mp 120-125 ${ }^{\circ} \mathrm{C}$; ${ }^{1} \mathrm{H}$ NMR $\left(500 \mathrm{MHz}, \mathrm{CDCl}_{3}\right) \delta 7.45(\mathrm{~s}, 1 \mathrm{H}), 7.02(\mathrm{~s}, 1 \mathrm{H}), 6.66(\mathrm{~d}, J=2.1 \mathrm{~Hz}, 1 \mathrm{H}), 6.42$ (d, $J=2.2 \mathrm{~Hz}, 1 \mathrm{H}), 3.99$ (s, 3H), 3.98 (s, 3H), 3.96 (s, 3H), 3.89 (s, 3H); ${ }^{13} \mathrm{C}$ NMR $(125$ $\mathrm{MHz}, \mathrm{CDCl}_{3}$ ) $\delta$ 157.3, 155.7, 150.4, 147.4, 130.8, 116.1, 105.9, 101.5, 97.7, 96.1, 56.0, 55.9, 55.6, 55.5; IR (film) 2999, 2937, 2833, 1633, 1610, $1513 \mathrm{~cm}^{-1}$; HRMS (ESI) calcd for $\mathrm{C}_{14} \mathrm{H}_{17} \mathrm{O}_{4}\left(\mathrm{MH}^{+}\right)$249.1127, found 249.1137. 


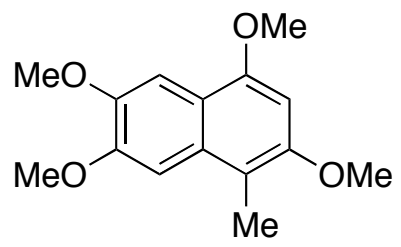

$3 e$

2,4,6,7-tetramethoxy-1-methylnaphthalene (3e): Orange amorphous solid; mp 134-140 ${ }^{\circ} \mathrm{C}$; ${ }^{1} \mathrm{H}$ NMR (500 MHz, $\mathrm{CDCl}_{3}$ ) $\delta 7.49$ (s, 1H), 7.12 (s, 1H), 6.57 (s, 1H), $4.02(\mathrm{~s}, 3 \mathrm{H})$, $4.00(\mathrm{~s}, 3 \mathrm{H}), 3.996(\mathrm{~s}, 3 \mathrm{H}), 3.92(\mathrm{~s}, 3 \mathrm{H}), 2.43(\mathrm{~s}, 3 \mathrm{H}) ;{ }^{13} \mathrm{C} \mathrm{NMR}\left(125 \mathrm{MHz}, \mathrm{CDCl}_{3}\right) \delta$ 153.9, 150.3, 147.4, 130.1, 116.3, 110.9, 103.8, 102.8, 101.5, 93.4, 57.6, 56.0, 55.9, 55.7, 10.6; IR (film) 2991, 2930, 2833, 16299, 1598, 1513, $1494 \mathrm{~cm}^{-1}$; HRMS (CI) calcd for $\mathrm{C}_{15} \mathrm{H}_{18} \mathrm{O}_{4}\left(\mathrm{M}^{+}\right)$262.1205, found 262.1204.

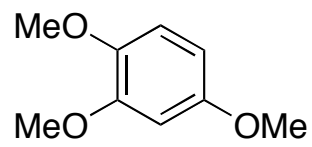

$3 f$

1,2,4-trimethoxybenzene (3f): Yellow oil; ${ }^{1} \mathrm{H}$ NMR $\left(500 \mathrm{MHz}, \mathrm{CDCl}_{3}\right) \delta 6.78$ (d, $J=$ $8.7 \mathrm{~Hz}, 1 \mathrm{H}), 6.51(\mathrm{~d}, J=2.8 \mathrm{~Hz}, 1 \mathrm{H}), 6.39$ (dd, $J=8.7,2.8 \mathrm{~Hz}, 1 \mathrm{H}), 3.85(\mathrm{~s}, 3 \mathrm{H}), 3.83$ (s, $3 \mathrm{H}), 3.76$ (s, 3H). Spectral data agreed with those reported previously: Mathivanan, N.; Cozens, F.; McClelland, R. A.; Steenken, S. J. Am. Chem. Soc. 1992, 114, 2198-2203 and Buchanan, G. L.; Raphael, R. A.; Taylor, R. J. Chem. Soc., Perkins Trans. 1 1973, 4 , 373-375.

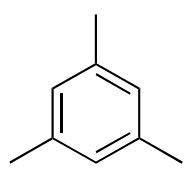

$3 g$

1,3,5-trimethylbenzene (3g): Brown amorphous solid; ${ }^{1} \mathrm{H}$ NMR $\left(500 \mathrm{MHz}, \mathrm{CDCl}_{3}\right) \delta$ $6.90(\mathrm{~s}, 3 \mathrm{H}), 2.43$ (s, 9H). Spectral data agreed with those reported previously: Kim, E. K.; Kochi J. K. J. Am. Chem. Soc. 1991, 113, $4962-4974$ and Hunt, D. F.; Sethi S. K. J. Am. Chem. Soc. 1980, 102, 6953-6963. 


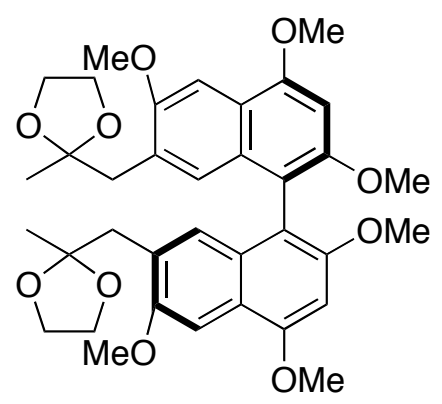

$3 h$

2-((1-(1-2,6,8-trimethoxy-3-((2-methyl-1,3-dioxolan-2-yl)methyl)naphthalen-5-yl)2,4,6-trimethoxynaphthalen-7-yl)methyl)-2-methyl-1,3-dioxolane (3h): $[\alpha]^{20}{ }_{D}-17.8(\mathrm{c}$ $0.53, \mathrm{CH}_{2} \mathrm{Cl}_{2},>99 \%$ ee); IR (thin film) $2933,2839,1595,1503,1463 \mathrm{~cm}^{-1} ;{ }^{1} \mathrm{H} \mathrm{NMR}$ (500 $\left.\mathrm{MHz} \mathrm{CDCl}_{3}\right) \delta 1.18(\mathrm{~s}, 6 \mathrm{H}), 2.75(\mathrm{~d}, J=13.5,2 \mathrm{H}), 2.99(\mathrm{~d}, J=13.5,2 \mathrm{H}), 3.44-3.55(\mathrm{~m}$, 4H), 3.65-3.74 (m, 4H), $3.70(\mathrm{~s}, 6 \mathrm{H}), 3.92(\mathrm{~s}, 6 \mathrm{H}), 4.11(\mathrm{~s}, 6 \mathrm{H}), 6.78(\mathrm{~s}, 2 \mathrm{H}), 7.01(\mathrm{~s}, 2 \mathrm{H})$, $7.51(\mathrm{~s}, 2 \mathrm{H}) ;{ }^{13} \mathrm{C} \mathrm{NMR}\left(500 \mathrm{MHz}, \mathrm{CDCl}_{3}\right) \delta$ 24.6, 37.9, 55.7, 55.8, 57.8, 64.7, 64.8, 95.4, 99.8, 110.3, 112.7, 121.6, 127.9, 129.2, 130.1, 154.1, 155.3, 155.4; HRMS (ESI) calcd for $\mathrm{C}_{36} \mathrm{H}_{42} \mathrm{O}_{10}\left(\mathrm{MH}^{+}\right)$635.2832, found 635.2843; CSP HPLC (Chiralpak AD, $1.0 \mathrm{~mL} / \mathrm{min}$, 95:5 hexanes: $i \mathrm{PrOH}) \mathrm{t}_{\mathrm{R}}(\mathrm{S})=14.7$ min, $\mathrm{t}_{\mathrm{R}}(\mathrm{R}) 17.5 \mathrm{~min}$.

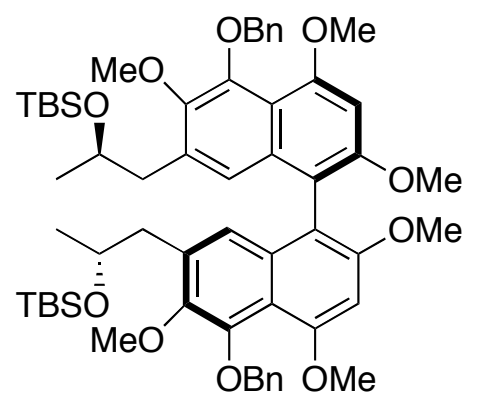

$3 \mathbf{i}$

$\left(2{ }^{\prime}, R, R_{\mathrm{a}}, 2{ }^{\prime}, ' R\right)-5,5 '$-Bis-benzyloxy-2,2',4,4',6,6'-hexamethoxy-7,7'-bis(2-

propyloxy(tert-butyl)dimethyl silane)-[1,1']binaphthalenyl (3i): ${ }^{1} \mathrm{H}$ NMR (500 MHz, $\left.\mathrm{CDCl}_{3}\right) \delta-0.23(\mathrm{~s}, 6 \mathrm{H}),-0.11(\mathrm{~s}, 6 \mathrm{H}), 0.73(\mathrm{~s}, 18 \mathrm{H}), 1.00(\mathrm{~d}, J=6.0 \mathrm{~Hz}, 6 \mathrm{H}), 2.46-2.42$ (dd, $J=7.1 \mathrm{~Hz}, 12.7 \mathrm{~Hz}, 2 \mathrm{H}), 2.83-2.79$ (dd, $J=6.3 \mathrm{~Hz}, 12.7 \mathrm{~Hz}, 2 \mathrm{H}), 3.70(\mathrm{~s}, 6 \mathrm{H}), 3.95$ $(\mathrm{s}, 6 \mathrm{H}), 4.00-4.02(\mathrm{~m}, 2 \mathrm{H}), 4.00(\mathrm{~s}, 6 \mathrm{H}), 5.08$ (br s, 4H), $6.74(\mathrm{~s}, 2 \mathrm{H}), 6.76(\mathrm{~s}, 2 \mathrm{H}), 7.37-$ $7.47(\mathrm{~m}, 6 \mathrm{H}), 7.64-7.66(\mathrm{~m}, 4 \mathrm{H})$. 


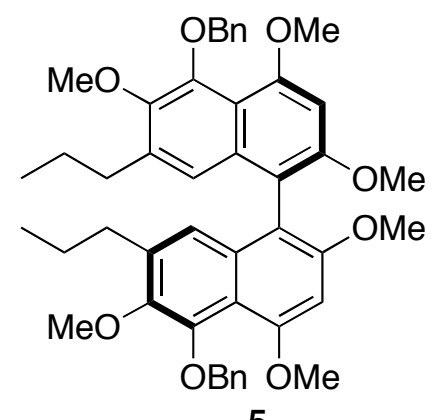

5

\section{5,5'-Bis-benzyloxy-2,2',4,4',6,6'-hexamethoxy-7,7'-dipropyl-[1,1']-binaphthalene}

(5): Resin; ${ }^{1} \mathrm{H}$ NMR (500 MHz, $\left.\mathrm{CDCl}_{3}\right) \delta 7.62$ (d, $\left.J=7.0 \mathrm{~Hz}, 4 \mathrm{H}\right), 7.43$ (t, $J=7.3 \mathrm{~Hz}$, $4 \mathrm{H}), 7.37(\mathrm{t}, J=7.3 \mathrm{~Hz}, 2 \mathrm{H}), 6.76(\mathrm{~s}, 2 \mathrm{H}), 6.64(\mathrm{~s}, 2 \mathrm{H}), 5.10(\mathrm{~m}, 4 \mathrm{H}), 3.99(\mathrm{~s}, 6 \mathrm{H}), 3.92$ $(\mathrm{s}, 6 \mathrm{H}), 3.74(\mathrm{~s}, 6 \mathrm{H}), 2.46-2.53(\mathrm{~m}, 4 \mathrm{H}), 1.35-1.42(\mathrm{~m}, 4 \mathrm{H}), 0.75(\mathrm{t}, J=7.2 \mathrm{~Hz}, 6 \mathrm{H}) ;{ }^{13} \mathrm{C}$ NMR $\left(125 \mathrm{MHz}, \mathrm{CDCl}_{3}\right) \delta 157.1,154.9,148.8,147.2,138.9,137.0,133.7,129.0,128.5$, 127.8, 122.1, 116.5, 112.5, 95.9, 76.2, 61.4, 57.5, 56.1, 32.8, 23.6, 14.0; IR (film) 2933, $1338 \mathrm{~cm}^{-1}$; HRMS (ESI) calcd for $\mathrm{C}_{46} \mathrm{H}_{50} \mathrm{O}_{8} \mathrm{Na}\left(\mathrm{MNa}^{+}\right)$753.3403, found 753.3427. 


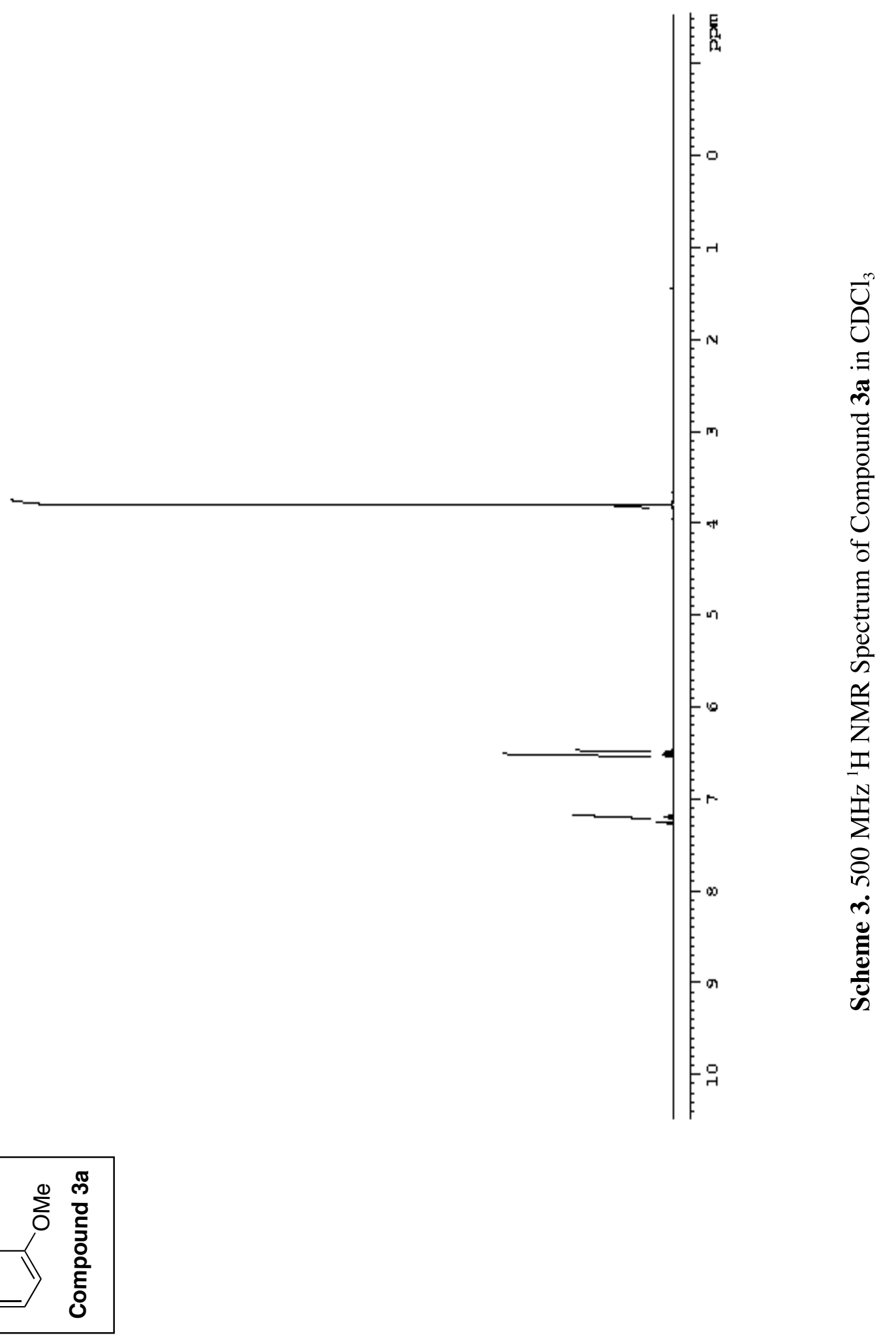




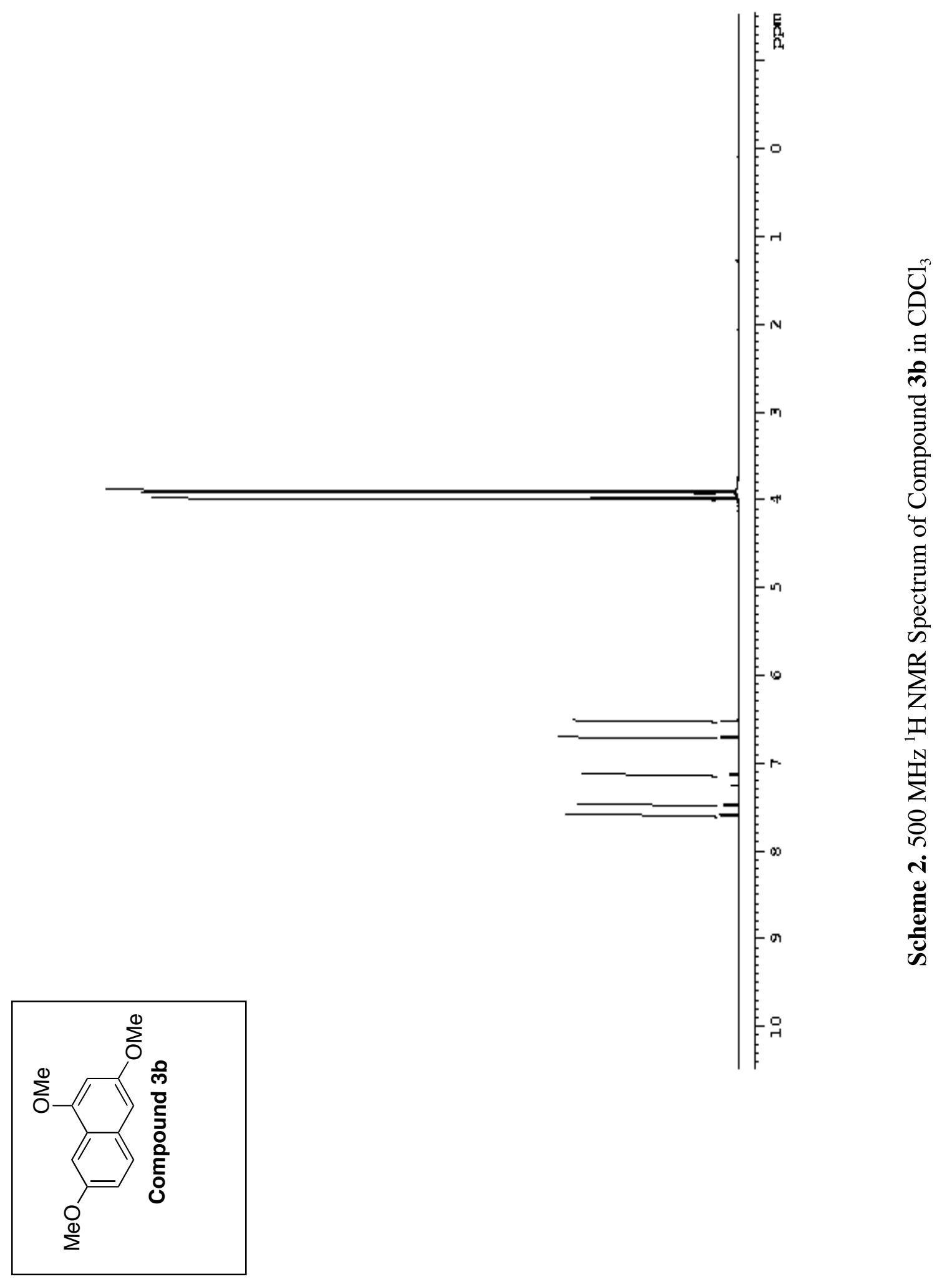



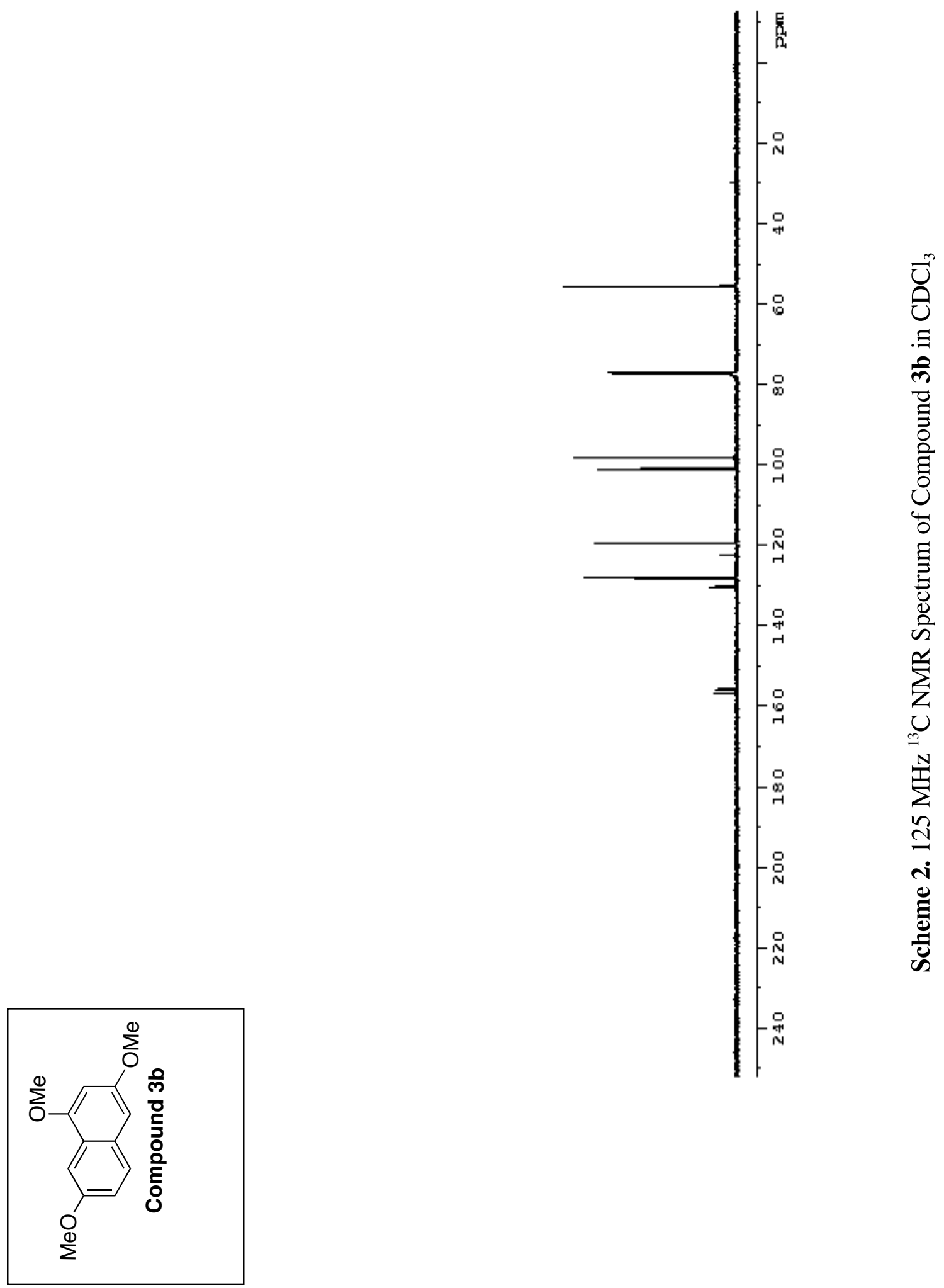


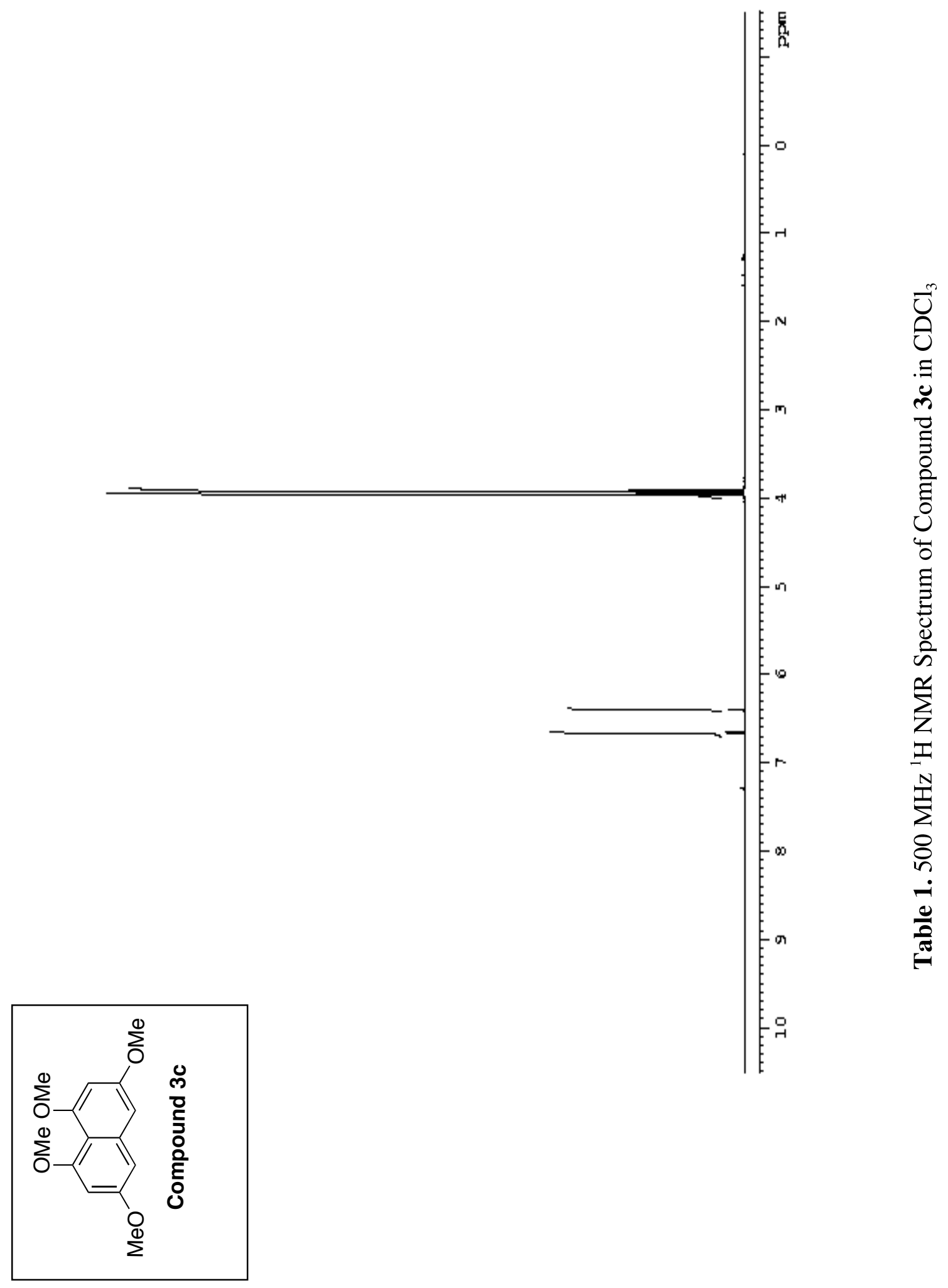



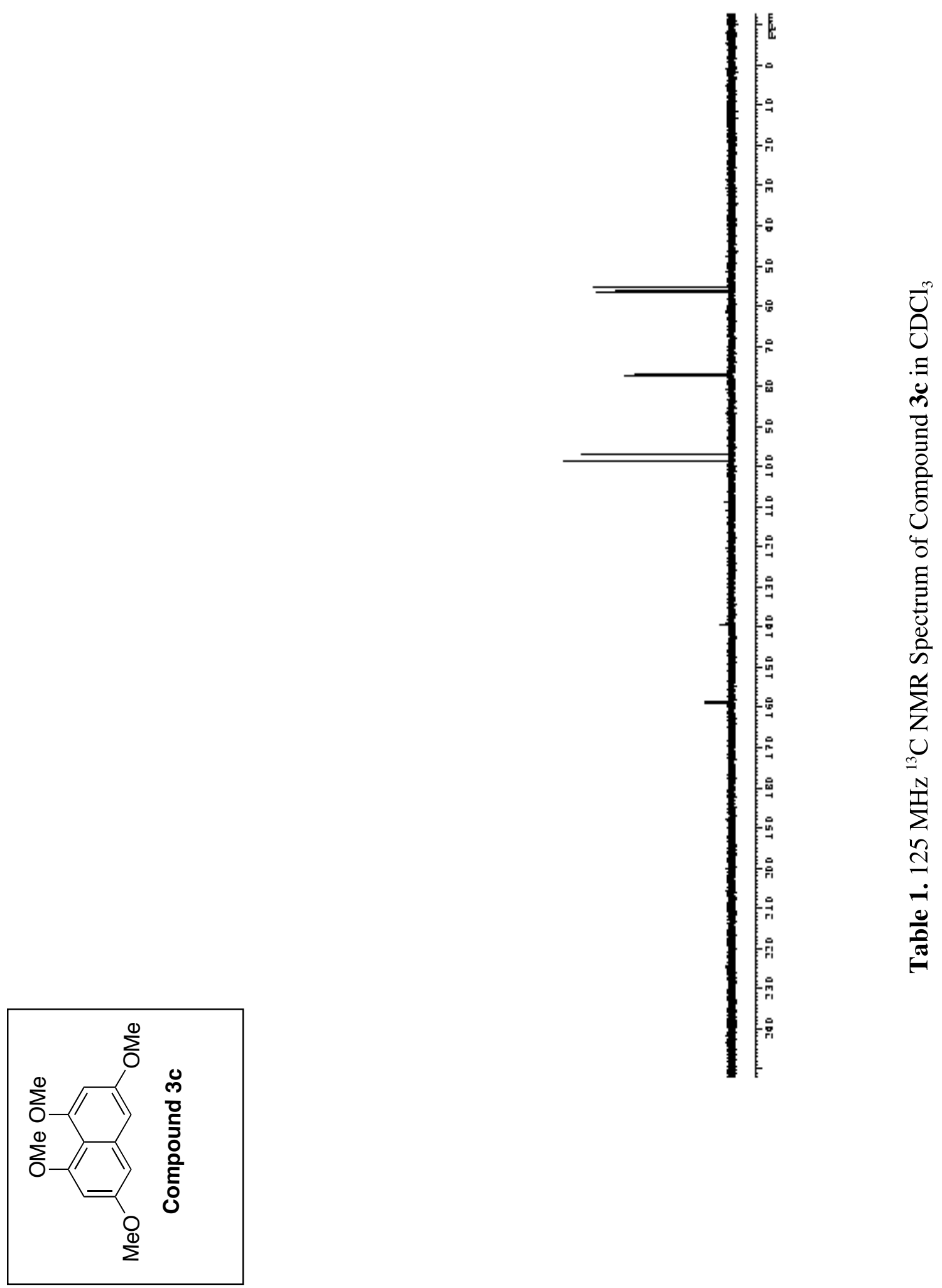


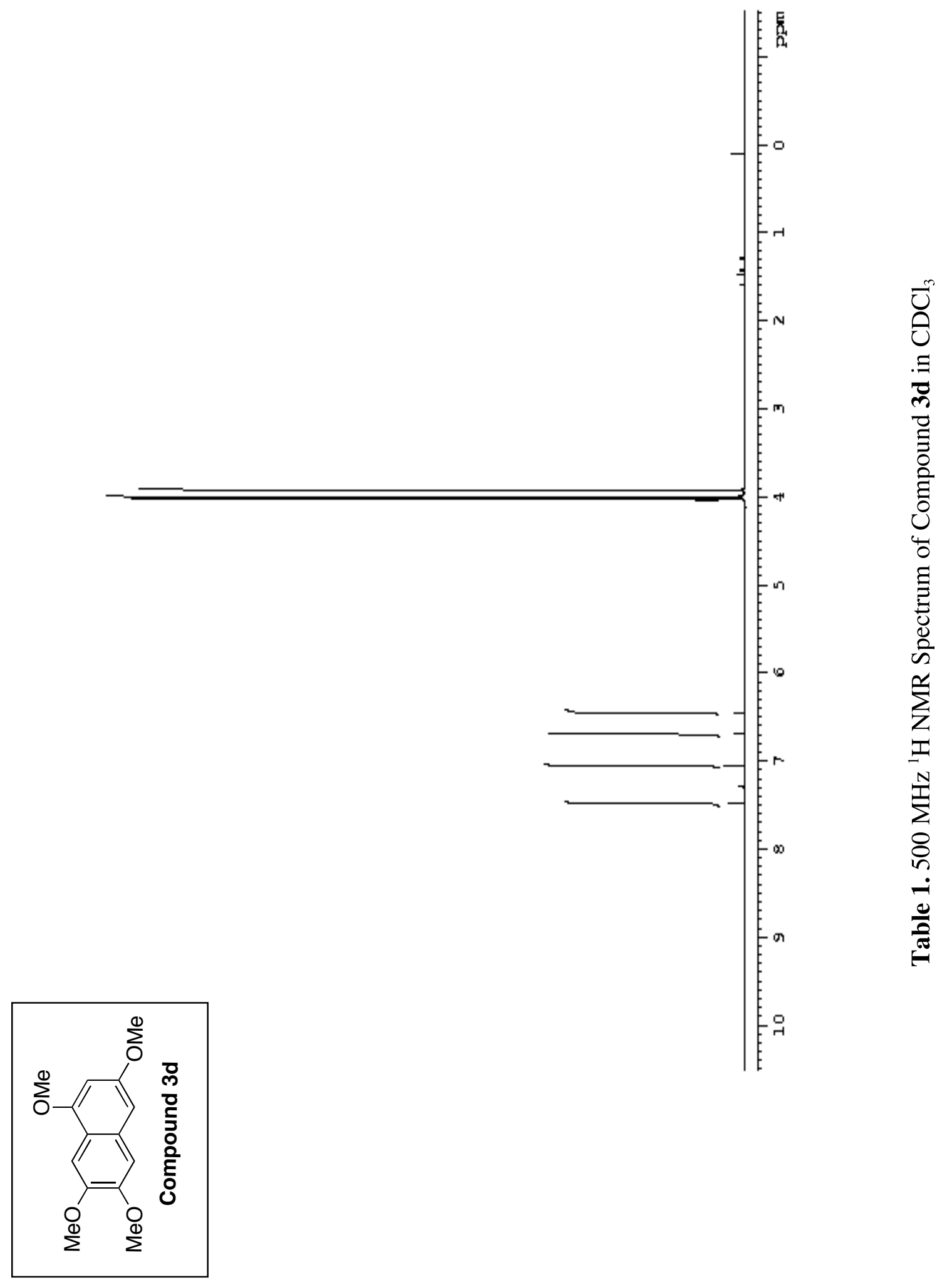



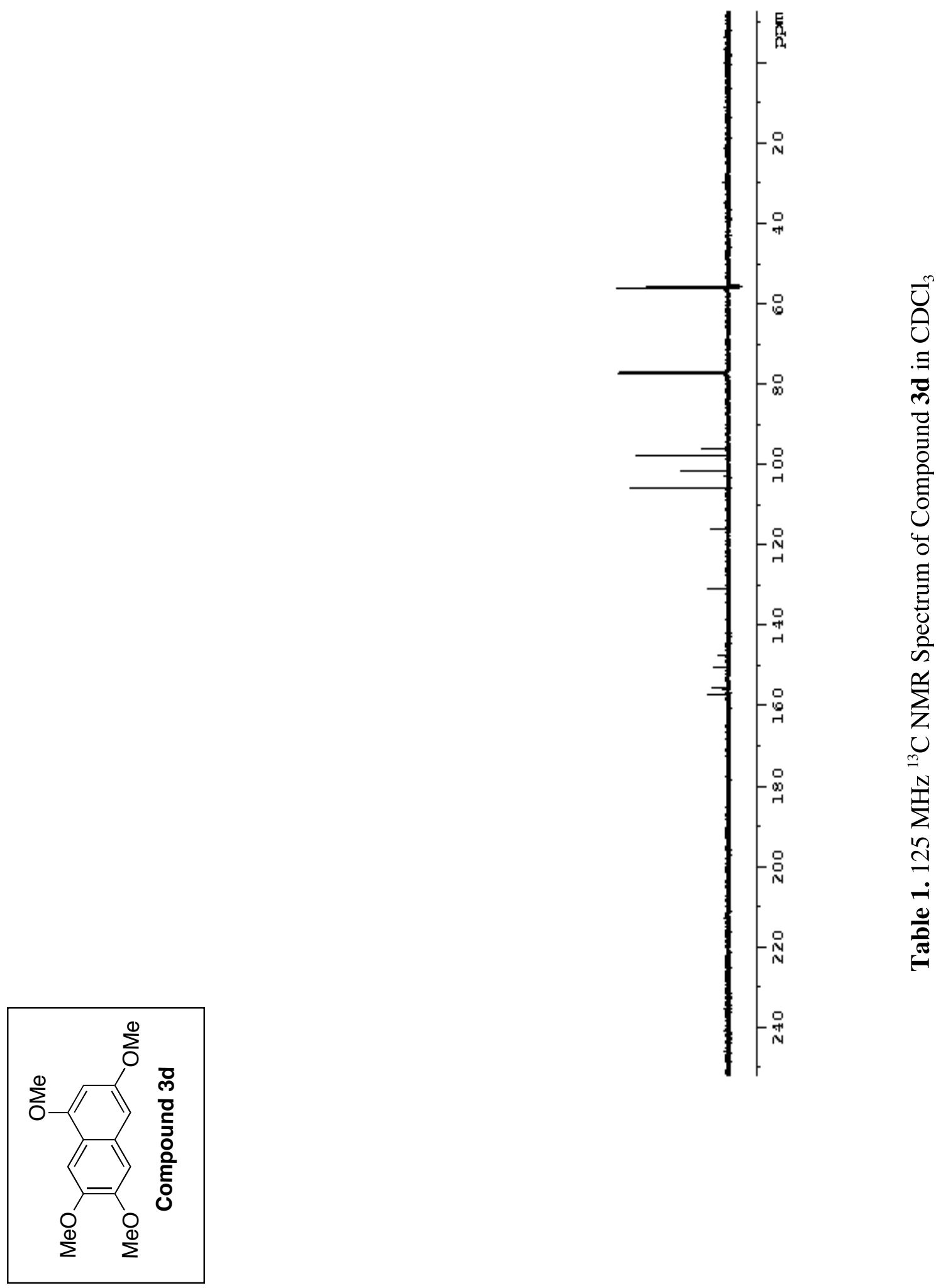


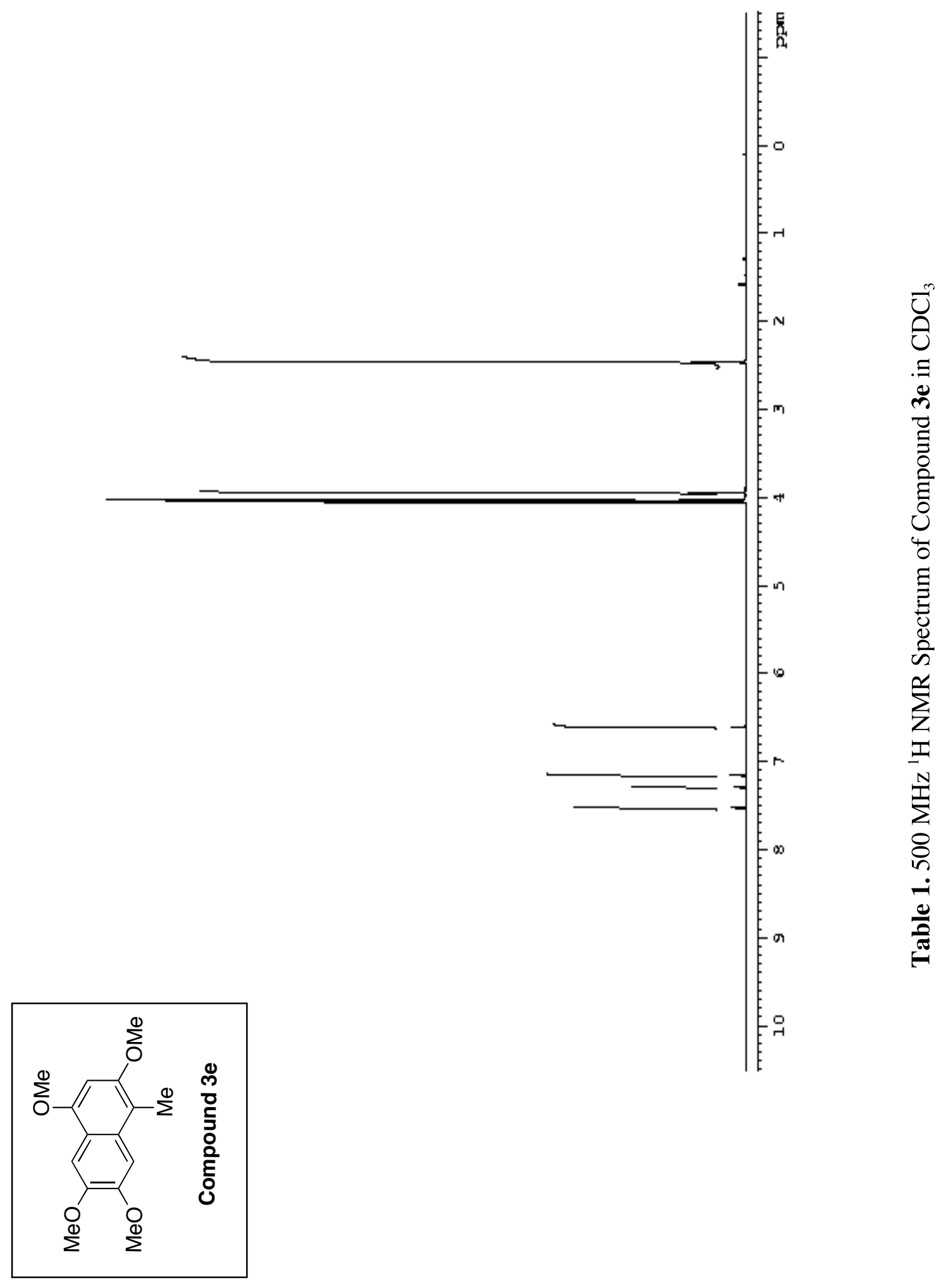




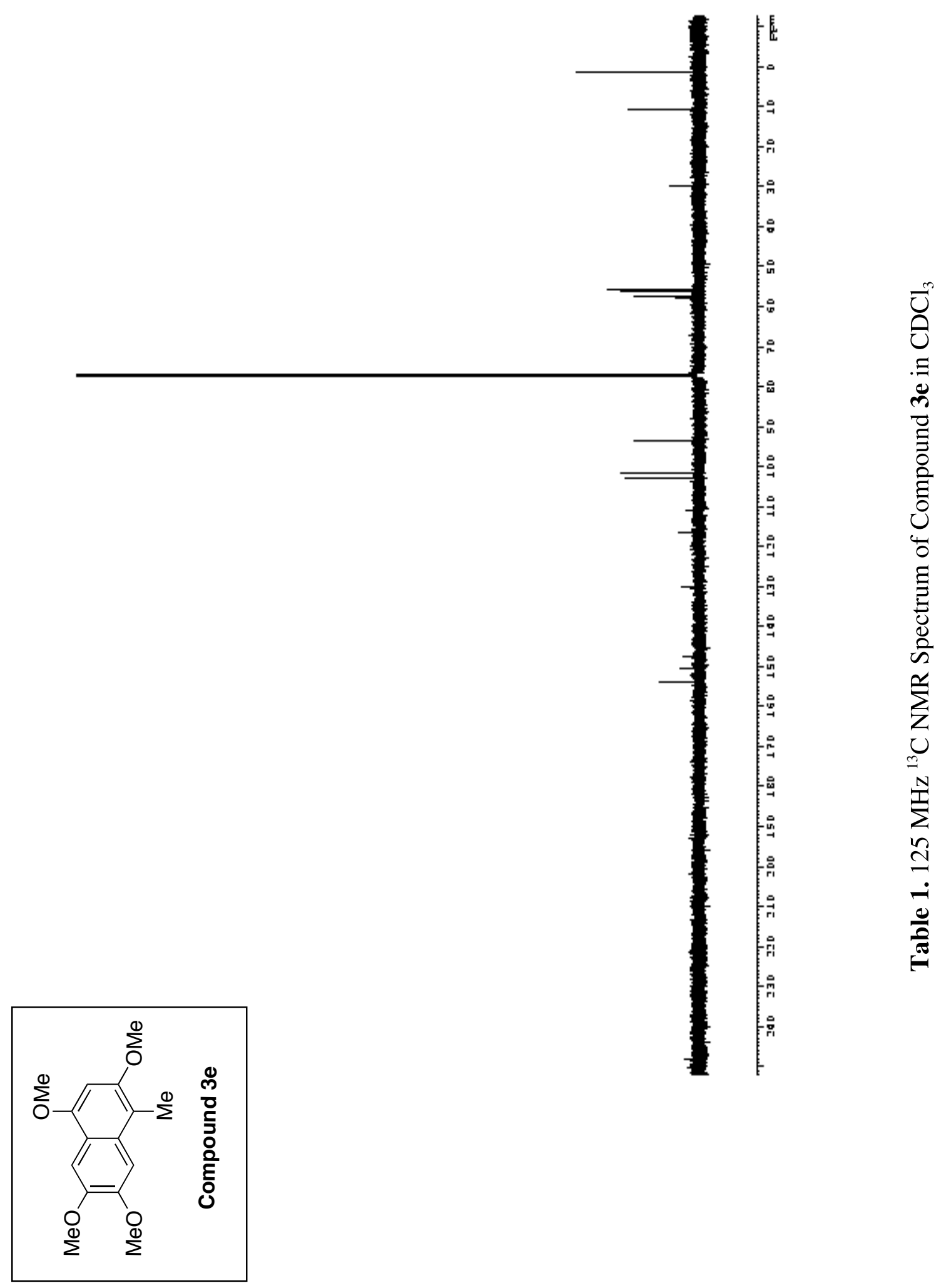




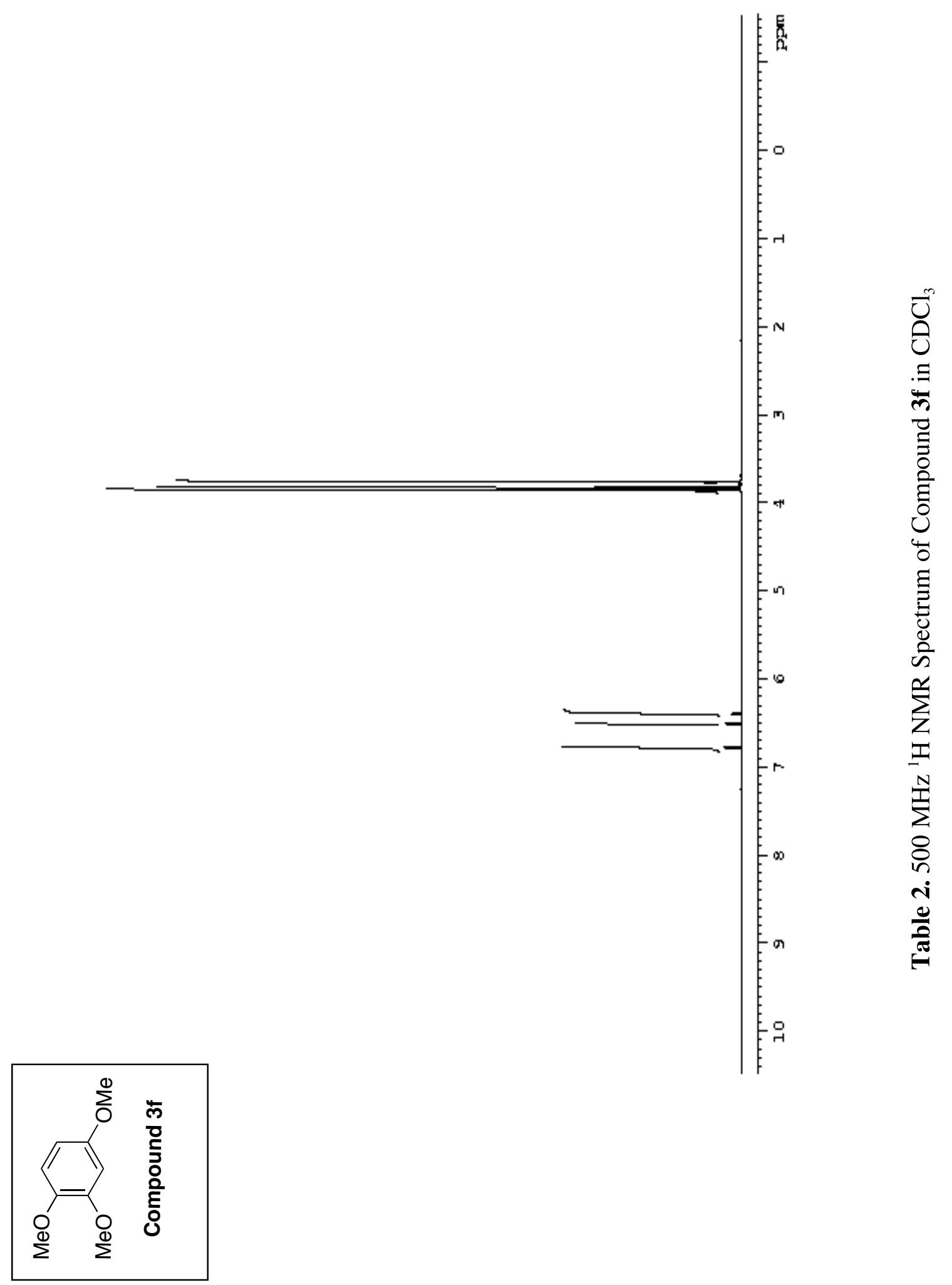



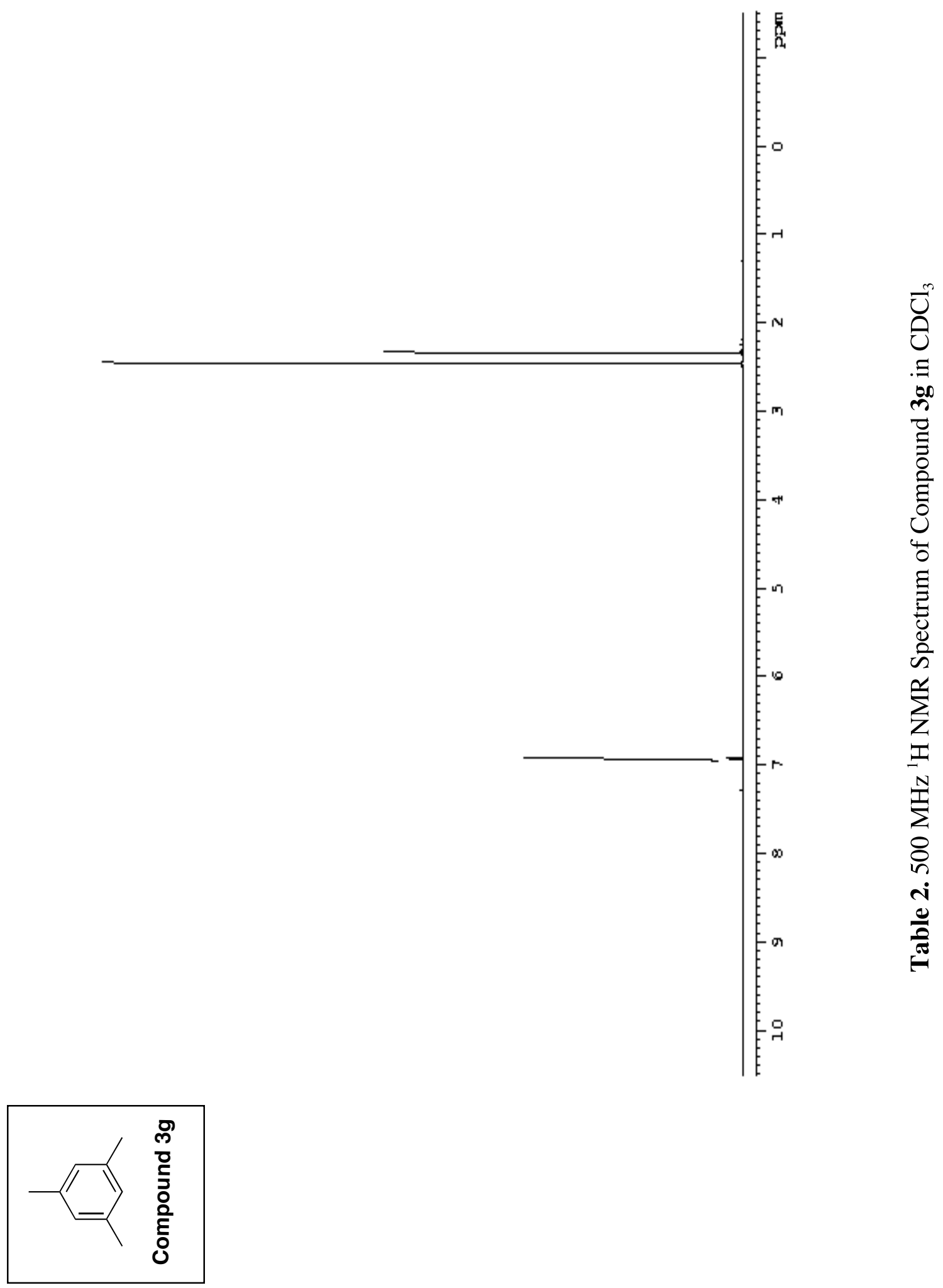


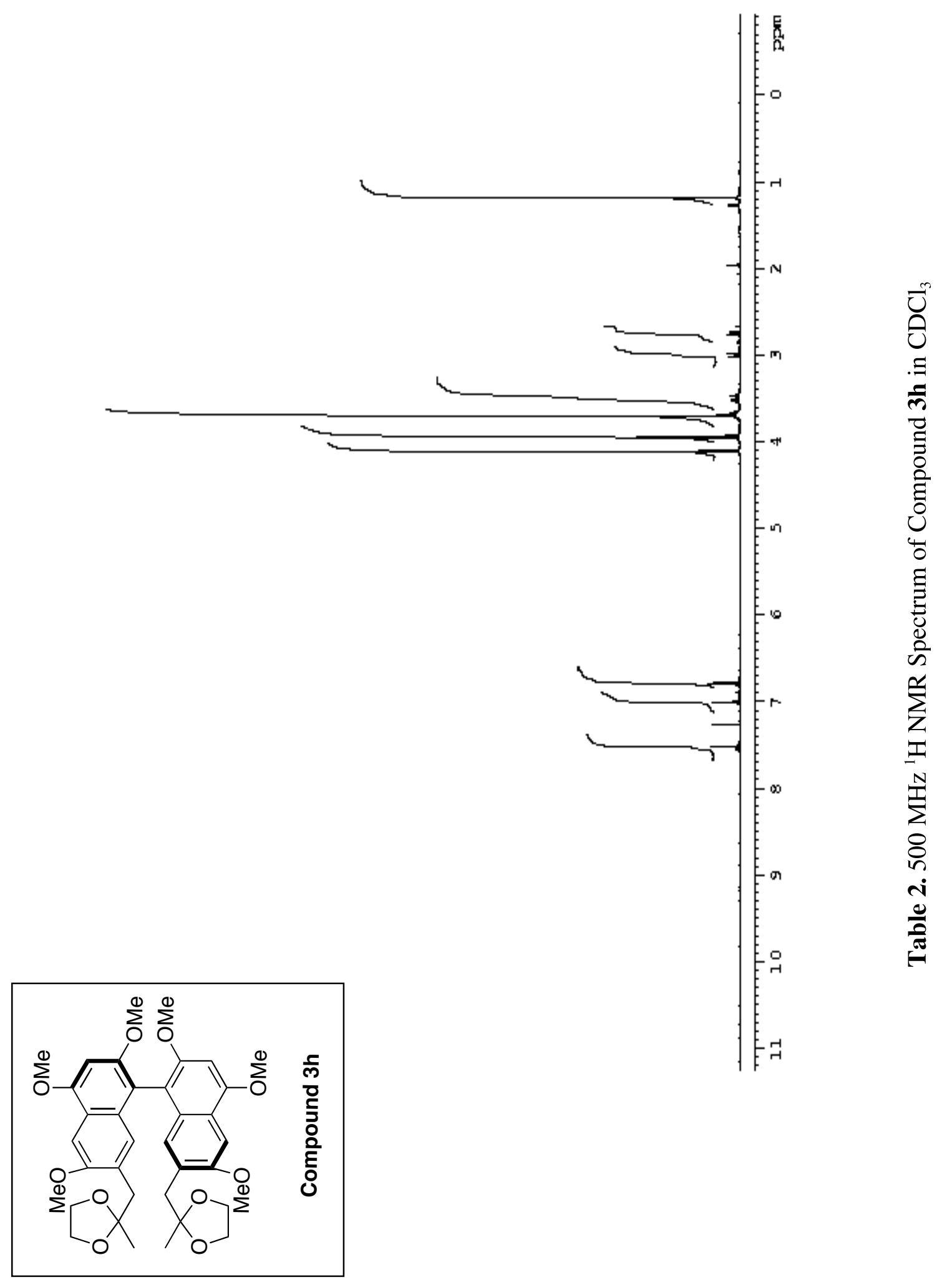



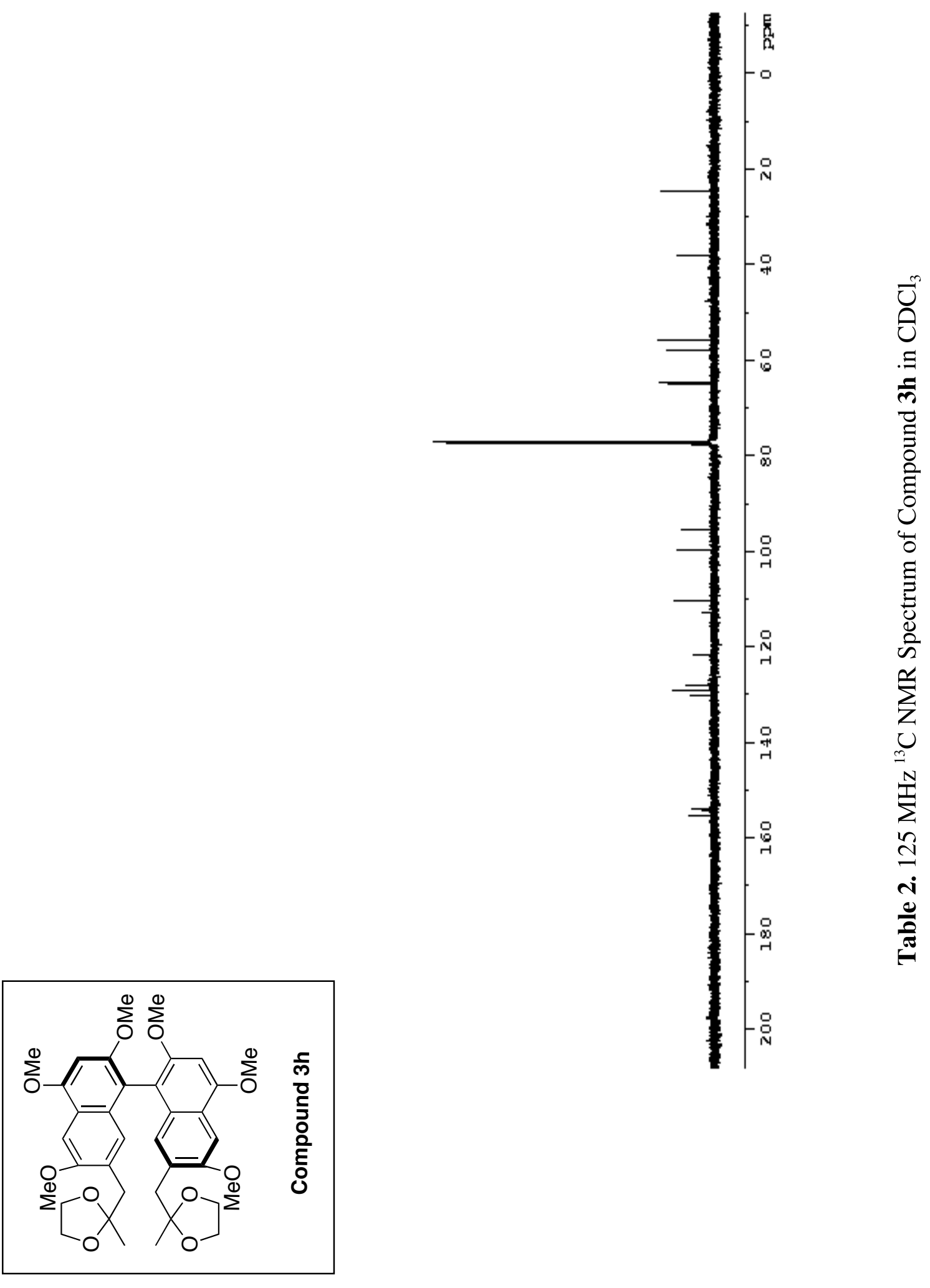


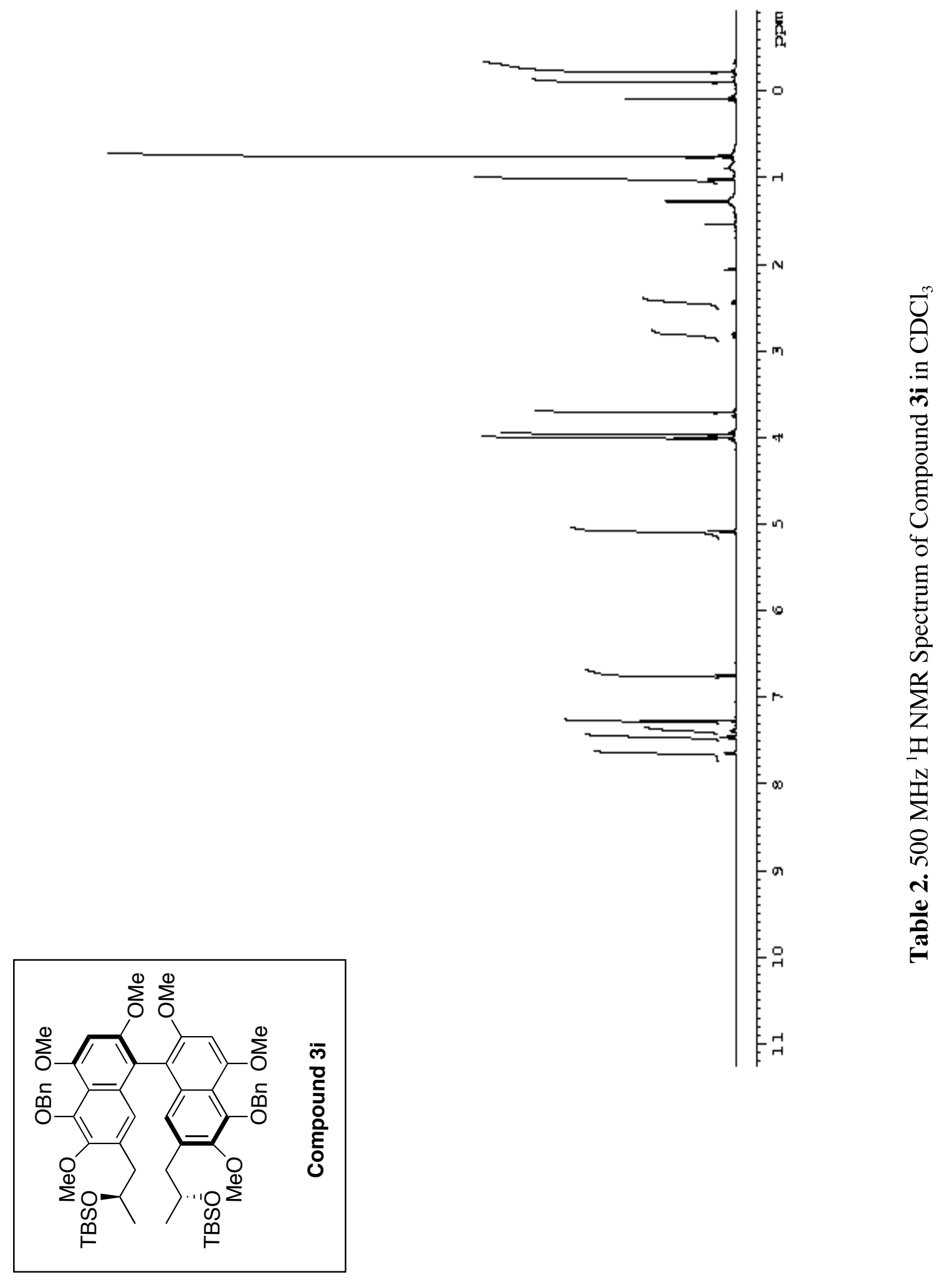




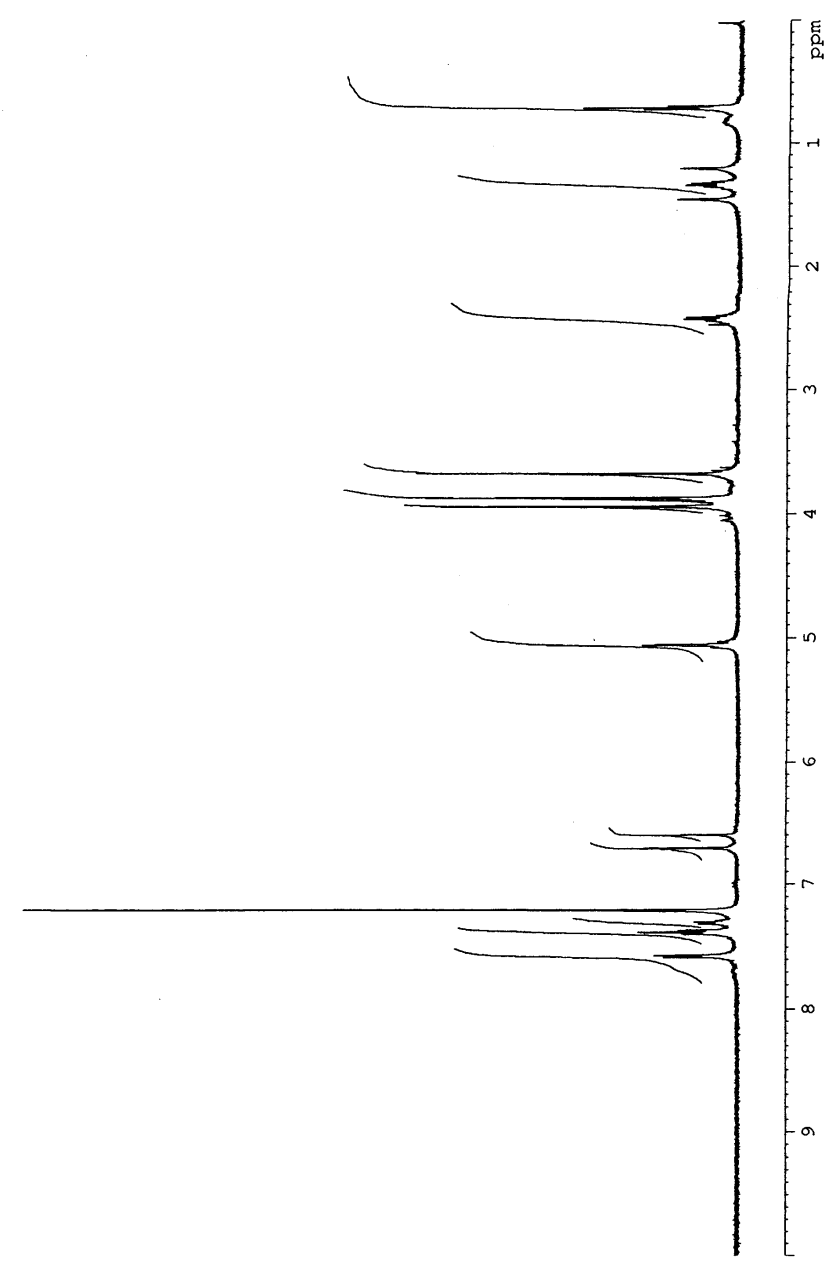

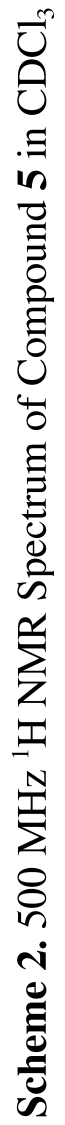

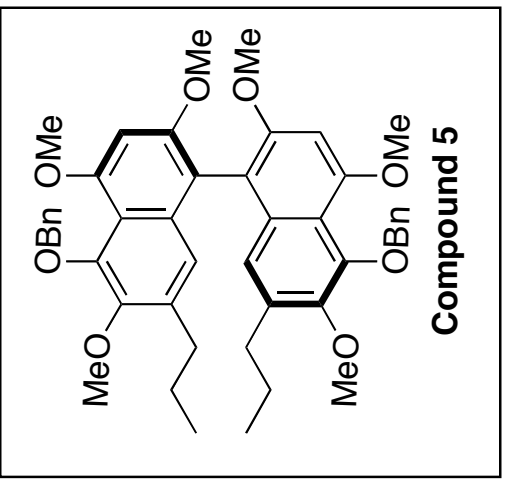




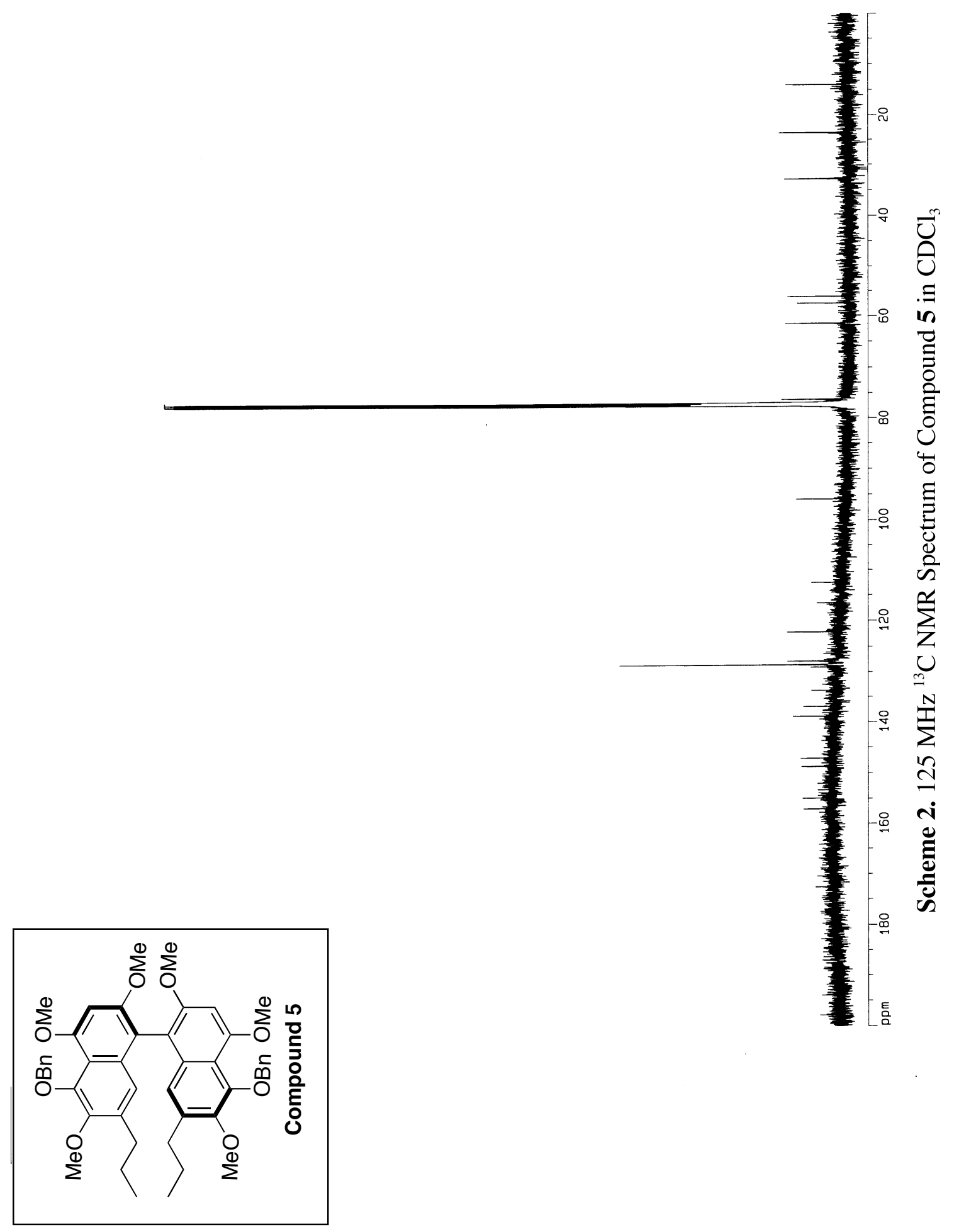

